University of South Florida

DIGITAL COMMONS

@ UNIVERSITY OF SOUTH FLORIDA
Digital Commons @ University of

South Florida

$1-1-2009$

\title{
Synthesis of Research on Value of Time and Value of Reliability
}

CUTR

Follow this and additional works at: https://digitalcommons.usf.edu/cutr_nctr

\section{Recommended Citation}

"Synthesis of Research on Value of Time and Value of Reliability," National Center for Transit Research (NCTR) Report No. CUTR-NCTR-RR-2008-03, Center for Urban Transportation Research, University of South Florida, 2009.

DOI: https://doi.org/10.5038/CUTR-NCTR-RR-2008-03

Available at: https://scholarcommons.usf.edu/cutr_nctr/154

This Technical Report is brought to you for free and open access by the National Center for Transit Research (NCTR) Archive (2000-2020) at Digital Commons @ University of South Florida. It has been accepted for inclusion in Research Reports by an authorized administrator of Digital Commons @ University of South Florida. For more information, please contact digitalcommons@usf.edu. 


\title{
Synthesis of Research
}

on

\author{
Value of Time \\ and \\ Value of Reliability
}

Final Report Contract No. BD549 46

January 2009

Florida Department of Transportation

Project Manager: Martin Markovich

Report by: Sisinnio Concas

Alexander Kolpakov

Center for Urban Transportation Research 
This research was conducted under a grant from the Florida Department of Transportation. The opinions, findings, and conclusions expressed in this report are those of the authors and not necessarily those of the Florida Department of Transportation.

iii Center for Urban Transportation Research | National Center for Transit Research 
Technical Report Documentation Page

\begin{tabular}{|c|c|c|c|}
\hline $\begin{array}{l}\text { 1. Report No. } \\
\text { BD 549-37 }\end{array}$ & 2. Government Accession No. & \multicolumn{2}{|c|}{ 3. Recipient's Catalog No. } \\
\hline \multirow{2}{*}{\multicolumn{2}{|c|}{$\begin{array}{l}\text { 4. Title and Subtitle } \\
\text { Synthesis of Research on Value of Time and Value of Reliability }\end{array}$}} & \multirow{2}{*}{\multicolumn{2}{|c|}{$\begin{array}{l}\text { 5. Report Date } \\
\text { January, } 2009\end{array}$}} \\
\hline & & & \\
\hline \multicolumn{2}{|c|}{$\begin{array}{l}\text { 7. Author(s) } \\
\text { Concas, Sisinnio, Kolpakov, Alexander }\end{array}$} & \multicolumn{2}{|c|}{$\begin{array}{l}\text { 8. Performing Organization Report No. } \\
7806\end{array}$} \\
\hline \multicolumn{2}{|c|}{$\begin{array}{l}\text { 9. Performing Organization Name and Address } \\
\text { National Center for Transit Research } \\
\text { Center for Urban Transportation Research } \\
\text { University of South Florida } \\
\text { 4202 E. Fowler Ave., CUT } 100 \\
\text { Tampa, FL 33620-5375 }\end{array}$} & \multicolumn{2}{|c|}{\begin{tabular}{|l|} 
10. Work Unit No. (TRAIS) \\
11. Contract or Grant No. \\
7806
\end{tabular}} \\
\hline \multicolumn{2}{|c|}{$\begin{array}{l}\text { 12. Sponsoring Agency Name and Address } \\
\text { Florida Department of Transportation, Office of Public Transportation } \\
\text { Transit Planning Program } \\
\text { Florida Department of Transportation } \\
\text { Office of Public Transportation } \\
605 \text { Suwannee Street, MS } 30 \\
\text { Tallahassee FL 32399-0450 }\end{array}$} & \multicolumn{2}{|c|}{ 14. Sponsoring Agency Code } \\
\hline \multicolumn{4}{|c|}{$\begin{array}{l}\text { 15. Supplementary Notes } \\
\text { FDOT Project Manager: Martin Markovich }\end{array}$} \\
\hline \multicolumn{4}{|c|}{$\begin{array}{l}\text { 16. Abstract } \\
\text { The objective of this study is to compile and synthesize current and past research on the value of } \\
\text { time (VOT) and the value of reliability of time (VOR). Findings are summarized into an application- } \\
\text { oriented document to provide practitioners with applicable ranges of estimates that can be used in } \\
\text { project evaluations. }\end{array}$} \\
\hline \multirow{2}{*}{\multicolumn{2}{|c|}{ 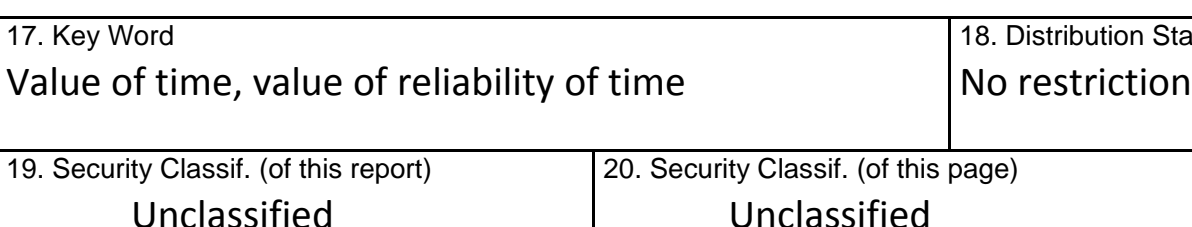 }} & ment & \\
\hline & & $\begin{array}{c}\text { 21. No. of Pages } \\
68\end{array}$ & 22. Price \\
\hline
\end{tabular}

Form DOT F 1700.7 (8-72) Reproduction of completed page authorized

iv

Center for Urban Transportation Research | National Center for Transit Research 


\section{Acknowledgements}

The authors wish to thank Mr. Martin Markovich of the Office of Public Transportation of FDOT for his guidance and support provided throughout the project. The document also benefits from the review and comments of Mr. Stephen L. Reich, Program Director at CUTR.

\section{FDOT Project Manager}

Martin Markovich

Florida Department of Transportation, Office of Public Transportation

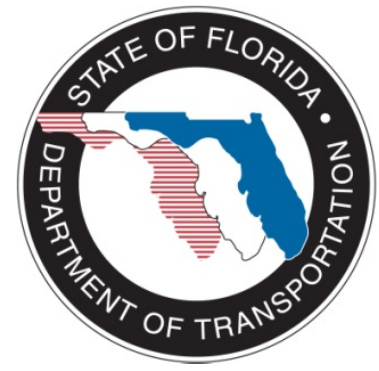

\section{CUTR Project Team}

Principal Investigator: Sisinnio Concas

Co-Principal Investigator: Alexander Kolpakov
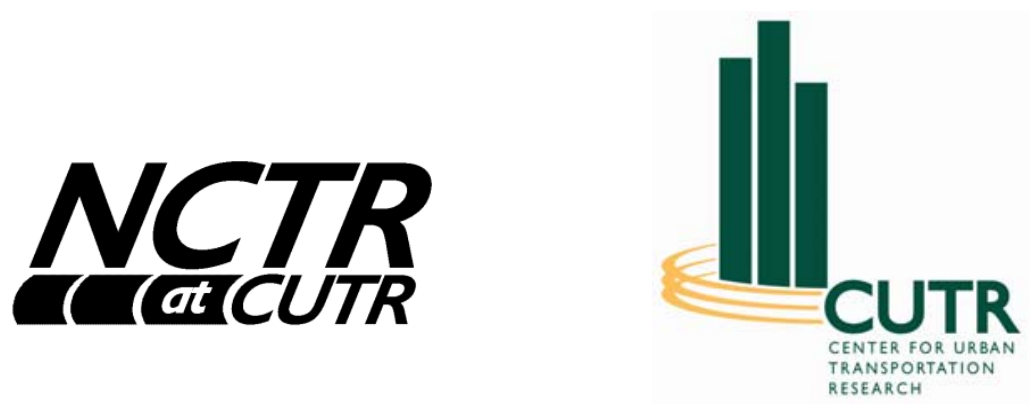

\section{Working Group}

Transportation Program Evaluation and Economic Analysis 
[This page intentionally left blank.]

vi Center for Urban Transportation Research | National Center for Transit Research 


\section{Executive Summary}

The objective of this study is to compile and synthesize current and past research on the value of time (VOT) and the value of reliability of time (VOR) to provide practitioners with applicable ranges of estimates.

The review of theoretical empirical literature attempts to clarify the complex issues of defining, modeling, and measuring VOT and VOR. Different theoretical approaches to defining VOT and VOR are discussed and an attempt is made to reconcile the existing differences. The complexities of VOT and VOR are revealed and estimation issues are summarized.

This report also provides an overview of the most cited empirical estimates of VOT and VOR. The discussion of empirical research is followed by a summary of estimates obtained from relevant studies, which are then reported in a concise tabular format.

In separate appendices, tables summarizing the main results of the theoretical and empirical studies of VOT and VOR are presented. These tables cover the vast body of research reviewed in this synthesis and are intended to serve as a quick reference for practitioners.

The comprehensive but concise summary of previous research, as well as the referenced values of VOT and VOR, will be valuable to practitioners for use as estimates in project evaluations.

The literature is continuously evolving with recent efforts aimed at presenting unified frameworks of analysis that explicitly account for this minimum-time constraint, and allow for the trade-off between discretionary and mandatory travel. Additional work is required to understand how travelers react to changes in travel time distributions, and to what extent these distributions affect travelers' decisions. Continuing research in these areas is warranted to create effective road pricing policies.

vii

Center for Urban Transportation Research | National Center for Transit Research 
[This page intentionally left blank.]

viii

Center for Urban Transportation Research | National Center for Transit Research 


\section{Table of Contents}

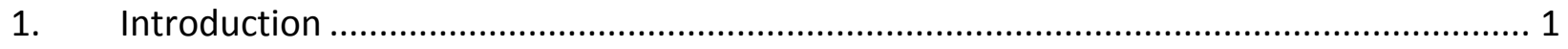

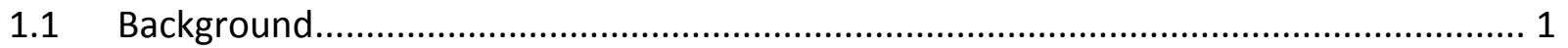

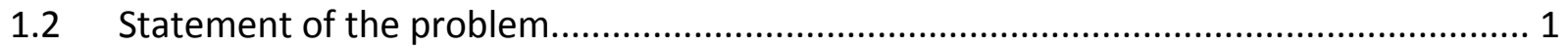

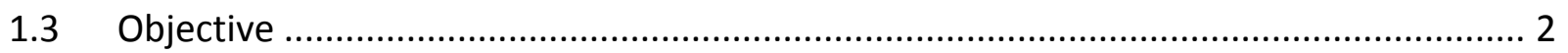

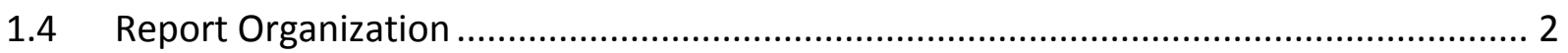

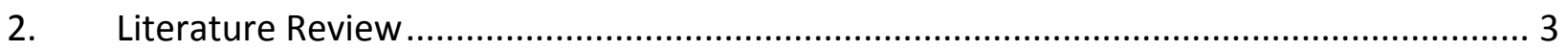

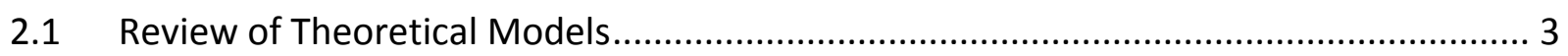

2.1.1 Definition of Value of Time............................................................................. 3

2.1.2 Value of Time Measurement Issues ............................................................................. 4

2.1.3 Definitions of Travel Time Reliability....................................................................... 7

2.1.4 Measures of Travel Time Reliability ...................................................................... 9

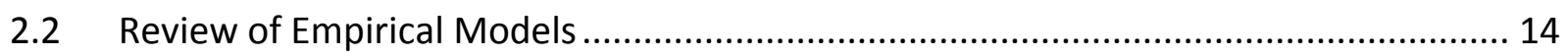

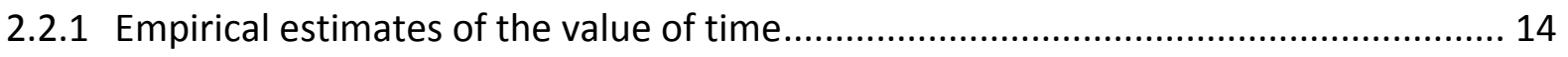

2.2.2 Empirical Measures of the Value of Travel Time Reliability........................................ 17

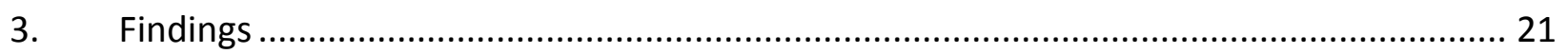

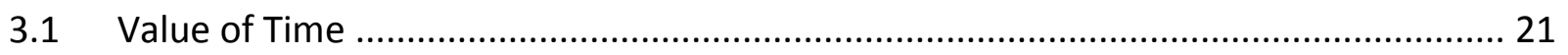

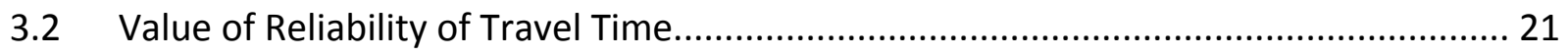

3.3 Guidelines and Suggestions................................................................................... 22

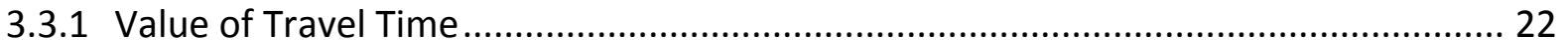

3.3.2 Reliability of Travel Time ……................................................................................. 23

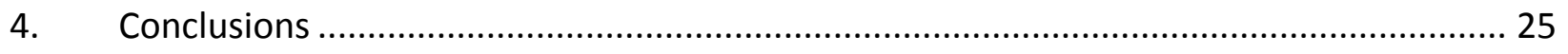

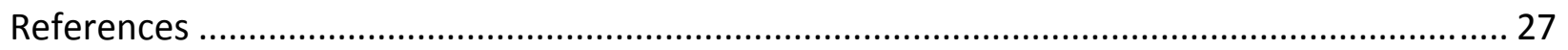

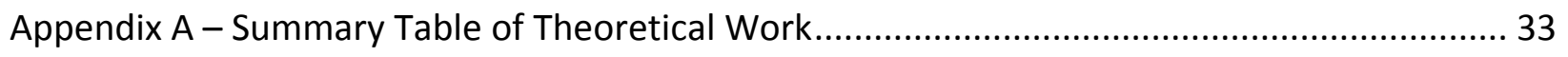

Appendix B - Summary Table of Empirical Work ……............................................................... 55

ix Center for Urban Transportation Research | National Center for Transit Research 


\section{Tables and Figures}

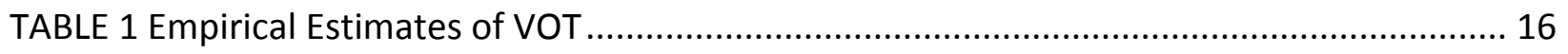

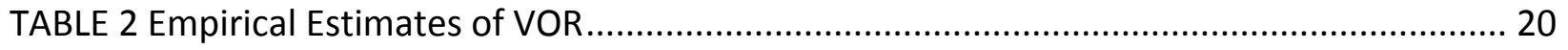

TABLE 3 Recommended Values of Travel Time ...................................................................... 23

TABLE 4 Recommended Value of Travel Time Reliability (VOR)........................................... 24 


\section{Introduction}

\subsection{Background}

U.S. highways have been funded largely by gas taxes, both at the national and state levels. This has resulted in a disconnect between roadway operators (state and local transportation agencies) and roadway users. Roadway operators cannot discern information about travelers' preferences based on their revealed choices and willingness to pay. This often results in highway investments that do not meet users' needs. In response to this issue, road pricing is becoming increasingly relevant as a measure for generating revenue, managing congestion, and improving travel time reliability.

As a result of the SAFETEA-LU Value Pricing Pilot Program, Florida transportation agencies are investigating the opportunity to introduce road pricing initiatives. This has resulted in an increased level of interest in incorporating high occupancy vehicle (HOV), high occupancy tolling (HOT) lanes, managed lanes and value pricing strategies into short and long-range plans. For example, several local transportation agencies have partnered together to develop the South Florida Managed Lane project which combines HOV lanes for express transit and managed lanes with value pricing to solve current and future congestion problems affecting heavily congested metropolitan areas.

Despite the compelling economic argument as a means to pay for additional transportation infrastructure, roadway pricing often lacks political support. Equity concerns for the effects of roadways congestion pricing on low income people and the difficulty to predict potential travel time savings for different demographic groups further influence public and political support. Therefore, a comprehensive synthesis of the current state of knowledge on how people value their travel time and reliability of travel time can be very helpful to transportation decision makers. A clear understanding of the concepts of travel time and travel time reliability, as well as the factors affecting their valuation, are crucial to developing an effective road pricing policy.

\subsection{Statement of the problem}

The primary barrier to successfully modeling the impacts of tolls on travel demand is the lack of reliable empirical data on the value of time (VOT) and how it varies by socio-demographic characteristics and trip purpose. Although VOT has been the subject for decades of substantial research, several areas of research and information sharing could improve the state of the practice in modeling road pricing strategies. One research area that is often overlooked is the 
empirical evidence that travelers value reliability as an important factor in trip making decisions. Reliability becomes particularly important in the value pricing of HOT lanes and managed lane applications, where tolls are adjusted based on traffic volumes to maintain desired levels of service. Reliability can be critical for travelers with rigid schedule requirements and is not necessarily correlated with a traveler's value of time. The vast body of research on this subject does not provide consistent estimates and guidelines for valuing travel time and reliability. Ad-hoc estimating methods and valuation approaches produce different, often conflicting, estimates.

\subsection{Objective}

The objective of this study is to compile and synthesize current and past research on the value of time and the value of reliability of time. The aim is to produce an application-oriented document to provide practitioners with applicable ranges of estimates. The effort also culls the more limited research on the value of time reliability, and identifies priority areas for further research.

This work is intended as a reference for practitioners and policy makers regarding the valuation of travel time and travel time reliability. Since research generally does not provide a unified approach to this topic, this document attempts to reconcile some of the existing differences by reviewing the estimation methods and empirical estimates, often found in research literature, accounting for the assumptions, limitations, and applicability of different research approaches. Given that the objective is to develop general guidelines rather than suggest universal rules that can be applied in all scenarios, the results of this synthesis should be viewed as general recommendations. They should be applied with caution, recognizing that individual circumstances and factors may affect the estimates herein summarized.

\subsection{Report Organization}

The study begins with a synthesis of work on the theoretical underpinnings to the study of the value of time. Chapter two summarizes what constitutes a vast body of work that has developed in the last 40 years. Chapter three summarizes findings and presents estimates and implications to practitioners. Chapter four concludes and provides directions for further research. 


\section{Literature Review}

There exists a vast body of literature on the theoretical underpinning of the value of time (VOT) and, to a lesser extent, the value of reliability of time (VOR). This synthesis considered over sixty articles, dating as early as 1965, that explicitly deal with behavioral models of consumer choice and travel behavior. The review summarizes the main concepts related to VOT and VOR and is intended as a summary of the current state of knowledge regarding modeling and estimation procedures.

This chapter provides a brief discussion of the key concepts, including the definitions of VOT and VOR, different modeling techniques, as well as conceptual difficulties related to their measurement. Relevant empirical models and provides a summary of empirical estimates of VOT and VOR are summarized. The review also discusses relevant factors proven to have an effect on the valuation of time and reliability.

Both theoretical and empirical research papers herein reviewed are summarized in tabular format. The summary tables, reported as appendices to this report, present a brief synopsis of work to date, highlighting major findings, estimates, and issues affecting the results. These tables are intended to be used as a reference for practitioners for a comparative assessment of the various research approaches in this field.

\subsection{Review of Theoretical Models}

\subsubsection{Definition of Value of Time}

The review found that the definition of value of time (VOT) is theoretically derived from a budget constrained allocation problem of time across various activities, such as work, leisure and the time required consuming goods and services. In its earliest derivations, the value of time is linked to the study of labor demand and supply. Time is a finite resource that can either be used for work or leisure. Thus it is equal to the opportunity cost, or the forgone wage, of an additional unit of leisure time. In this allocation problem, the value of time is thus equal to the hourly wage rate.

Time as an input, rather than just a commodity, was not explicitly introduced into the model of consumer choice until the 1950's, with Becker's (1965) explicit treatment of time as an input in the production of household goods, such as child rearing and other household chores. The acknowledgment of time as an input has nontrivial consequences in the field of transportation research. By recognizing that the demand for travel is derived from the demand for goods and 
services requiring out-of-home travel, the value of time takes different meanings. When deciding what to consume, how much and how frequently, individuals must also consider that consumption requires travel and that travel alone requires time. This theory contrasts with the classical budget constrained utility maximization theory, where goods are the only source of satisfaction.

DeSerpa (DeSerpa, 1971) delved further by considering that goods consumption requires the allocation of some minimum amount of time. This led to the distinction between the value of saving time, the value of time as a resource and the value of time as a commodity (Jara-Diaz, 2003). This assumption implies that time spent in any activity is partly a matter of choice, and partly a matter of necessity. When perceived as a necessity, an additional binding constraint is explicitly introduced. In turn, this constraint is not effective when time allocation becomes solely a matter of choice and time prices have no effect on the consumer's decision (DeSerpa, 1971). Using DeSerpa's approach, it has been demonstrated that the inclusion of minimum time requirements and discretionary time allocations potential leads to different marginal values of time (Palmquist, et al., 2007).

Virtually all early labor and recreation demand literature assumes that the value of individual's time in an activity is at a maximum equal to the wage rate, some fraction of it, and zero at a minimum (Shaw, 1992). This theory, though, ignores that goods consumption cannot be realized without incurring travel or communication costs.

In this context it is relevant to distinguish between the value and the cost of time. The value of time represents a subjective marginal benefit of time spent in a certain activity, while the opportunity cost of time reflects the net benefit of time spent in the next best alternative activity. Thus, the opportunity cost of time is influenced not only by the wage rate (directly) but also by the activity a person is engaged in, as well as the list of the alternative activities available. And since the decision to switch from one activity to another is made at the margin, the timing of the decision regarding time allocation needs to be considered as well. In other words, since individuals may allocate time differently at different times (time of year, or week, or day), the next best alternative activity depends heavily on the timing of the decision.

\subsubsection{Value of Time Measurement Issues}

The above developments in the consumer theory have significant implications. They provide evidence that not only can the value of time differ among individuals, but that it can also vary for the same individual depending on the particular timing a trip is undertaken. The prevailing average wage rate, traditionally used as a proxy for the value of time, is not an accurate measure of the value of time. Both theoretical and empirical research indicates that the value 
of time can be significantly higher or lower than the current wage rate of an individual depending on activities people are involved in (Jara-Diaz, 2002). Gronau (1976), for example, argues that the value of time depends mostly on the marginal wage rate, while the average wage rate can provide only a crude approximation of that value. This problem arises because the marginal wage is not directly observable. Thus, the difference between the value of time and the observable average wage rate can be caused by such factors as the costs incurred through work, the marginal disutility of work, the marginal utility of travel, the possibility of engaging in other activities while traveling, institutional barriers to changes in the number of working hours, and other factors.

An important implication of this distinction is that individuals with no observable market wage do not necessarily have a low or zero value of time. Similarly, low wage or unemployed individuals do not necessarily have a low opportunity cost of time (Shaw, 1992). The literature acknowledges that the correct estimation of travel time is extremely important for transportation modeling and the evaluation of infrastructure projects. User travel time savings are the most relevant component of benefits of urban transportation projects (typically 60 to 80 percent of total benefits), making reliable estimation extremely important for planning decisions (Litman, 2007).

The interpretation of value of time depends on how the time allocation problem is modeled. Johnson (Johnson, 1966) for example, views travel time only as a cost thus keeping it out of the utility function. DeSerpa (1971), allows time to be included in the utility function and thus has a commodity value. The consequence is a different valuation of the value of commuting time. In DeSerpa (DeSerpa, 1971) commuting time is defined as the value of time saved or the difference between the scarcity value (based on alternative use of time) and the commodity value of time. Different ways of modeling consumers' utility maximization problem has a profound effect on the way the value of time is measured. When time is only included in the constraint function, it is treated only as cost and acts as a budgetary constraint to consumption. In this case, time does not have a value per se and can't directly affect the utility. When time is included in the utility function, time gains commodity value and can directly influence consumer's utility. As a result, aside from its time constraint aspect, travel time can also cause a direct utility or disutility to travelers. In Johnson (Johnson, 1966), for example, commuting time does not yield any disutility, while in DeSerpa (DeSerpa, 1971) it can.

Shaw (1992) demonstrates that, while being totally opposite to each other, both approaches could be valid since there is no a priori reason to model time allocation problems in any particular manner. Ultimately, it is the specification of each model and inherent assumptions that will have significant impact on the way time is defined and measured. Reichman (1976) 
concludes that time savings are just as important to the travelers as other attributes of the trip, such as comfort, scenery, physical and mental efforts. This approach may explain why people may be willing to pay for using tollways even when they provide relatively small time savings. Accordingly, it is possible that traveling on tolled roads provides less disutility for the motorists, in the form of a more pleasurable, less stressful ride due to improved driving conditions. In other words, when facing a money-time trade-off, travelers react to the total cost of the trip, as determined by the sum of time and utility loss, rather than by the cost of travel time alone. Thus, people sometimes choose slower but more pleasant travel options, reflecting their lower total time cost, or they can be willing to pay extra for more comfortable seats, air conditioning, reduced transfers, etc. (Litman, 2007).

As a result, it often becomes difficult to separate the pure value of travel time from other trip attributes affecting travelers' willingness to pay. Hensher (1976) argues that most empirical studies of travel mode choices fail to separate the pure value of time, which is mode-abstract, from the comfort and convenience features of the trip that affect the composite value of travel time. Numerous travel time studies (cited by Hensher) lead to a general conclusion that the value of travel time savings is a function of income, although the valuation can vary from study to study.

Litman (2007) argues that while making their choices travelers react to the perceived travel time, which can be different from actual travel time. Travelers often tend to overstate congestion-related delays and understate the benefits from saving travel time. This can lead to the differences in travel time estimates obtained from empirical studies based on stated preferences and revealed preferences.

Since trade-off decisions are made at the margin, researchers argue that the value of time depends mostly on the marginal wage rate, while the average wage rate can provide only a crude approximation of that value (Gronau, 1976). Empirically, the problem arises because the marginal wage is not directly observable. Thus, the use of the average wage rate as a proxy may not always produce accurate results. The difference between the marginal value of time and the observable average wage rate can be caused by factors such as the costs incurred through work, the marginal disutility of work, the marginal utility of travel, the possibility of engaging in other activities while traveling, institutional barriers to changes in the number of working hours, and other factors (Gronau, 1976).

Finally, some researchers also point to the phenomenon that people often place value exclusively on the ability to control their time, irrespective of its utility or opportunity cost 
(Reichman, 1976). Thus, the value consumers place on saving time has more dimensions than simply opportunity cost of time measured by the money wage rate.

In conclusion, the literature review of the theoretical models found that there is no unique definition of the value of time. Through the review of the literature, it is shown that the value of time hinges on the assumption of a minimum-time constraint that requires individuals to travel more than they would choose to travel without the constraints.

The literature is in continuous evolution with recent efforts aimed at presenting unified frameworks of analysis that explicitly account for this minimum-time constraint, and allow for the trade-off between discretionary and mandatory travel (Anas, 2007, Anas and Xu, 1999).

\subsubsection{Definitions of Travel Time Reliability}

Traditionally, the value of travel time has been considered one of the largest cost components in benefit-cost analysis of transportation projects, as the reduction of travel time is usually regarded as the main source of benefits for travelers from the improvement of a transportation facility. However, in the presence of substantial road congestion, the reliability of travel time may be more important than travel time savings, particularly when travelers have constrained schedules (Tseng, et al., 2005).

The concept of travel time reliability is related to the experienced randomness in travel time (Tseng, Ubbels and Verhoef, 2005). From a user's perspective, increased variability in travel time makes trip scheduling difficult by introducing uncertainty. Faced with variability, travelers have to budget a time-cushion in their trips, which can potentially cause additional time losses. While arriving early does not necessarily entail disutility, it is not always a favorable outcome either because the time saved is not always easily converted into productive time. There is empirical evidence that while individuals are more averse to being late than being early, being early causes a disutility (Small, 1982).

Numerous studies have shown the importance of travel time reliability in traveler's choice behavior. It is argued that travel time reliability measures can provide better estimates of the benefits of transportation improvements (Tseng, Ubbels and Verhoef, 2005). Research demonstrates that improved reliability is a desired outcome of many transportation policies as it reduces scheduling costs and provides significant users benefits (Tilahun and Levinson, 2006, Tseng, Ubbels and Verhoef, 2005).

There exist several ways to define travel time reliability. As reviewed in Elefteriadou and Cui (2007), these definitions fall under two main categories: a) operationally-based and b) 
variability-based. While the first approaches focus on system performance evaluation and monitoring, variability-based approaches center on the traveler's perspective.

For example, Lomax et al. (2003) define reliability as the impact of non-recurrent congestion on the transportation system. National Cooperative Highway Research Program (NCHRP) Report 399 defines travel time reliability as a measure of variability that can be measured using the standard deviation of travel time (1998). In the 1998 California transportation plan (1998), reliability is defined as the level of variability between the expected and actual travel time (however, this approach does not clearly define a level that can be considered reliable).

In a recent report, the Federal Highway Administration (FHWA) provides a more formal definition of travel time reliability defining it as the consistency or dependability in travel times, as measured from day-to-day and/or across different times of the day (FHWA, 2006). In other words, travel time reliability measures the extent of unexpected delay in roadway travel. While drivers usually can adjust their schedules and budget extra time to account for expected traffic delays, they are more vulnerable and less tolerant to unexpected delays, due to its unpredictability. FHWA recommends that transportation planners consider travel time reliability a key performance measure in evaluating transportation projects.

The Florida Department of Transportation (FDOT) defines reliability as the percentage of travel that takes no longer than the expected travel time plus a certain acceptable additional time (FDOT, 2000). This approach, while clearly defining a threshold of unacceptable variability, relies on the value of median travel time, which may change from year to year and may present difficulties in tracking reliability over time (Elefteriadou and Cui, 2007).

The Texas Transportation Institute (TTI) Urban Mobility Report makes a distinction between variability and reliability of travel time. Variability is refers to the amount of inconsistency of operating conditions, while reliability refers to the level of consistency in transportation service (2003)..

A report by the American Association of State Highway and Transportation Officials (AASHTO) defines reliability as the percent of on-time performance for a given time schedule as it applies to freight transportation (AASHTO, 2000).

A recent travel time reliability report prepared for FDOT defines reliability as the percent of trips that reach their destination over a designated facility within a given travel time (or equivalently, at a given travel speed or higher) (Elefteriadou and Cui, 2007). 


\subsubsection{Measures of Travel Time Reliability}

The review found that there are two general approaches to measuring travel time reliability, the mean-variance and the scheduling approach. The mean-variance approach assumes that travelers endure inconvenience and costs when variability directly affects their travel time. Mean-variance models use cost functions and quantify variability using measures of dispersion to describe the variation in their distributions. This approach assumes that variability costs are symmetric with respect to the mean travel time (i.e., being late imposes the same costs as being early).

The scheduling approach explicitly distinguishes between the costs associated with late and early arrivals. This approach indirectly captures the costs of travel time variability through the modeling of travelers' departure time choices. Faced with variability in travel time, travelers move their departure times in order to change the probability of arriving too late or too early.

Although, there is evidence that under certain circumstances both the mean-variance and scheduling approaches are equivalent, there is a general agreement that scheduling models capture travelers' reaction to travel time variability more accurately (Noland and Polak, 2002). However, the estimation of scheduling models requires data on the distribution of travelers' arrival times and usually relies on simulation procedures. Mean-variance models, while less accurate, are easier to apply since they only require aggregate traffic data (mean and variance of travel time), a factor that explains their greater popularity. Ultimately, the choice of the approach to model travel time variability is determined by the purposes of the analysis and the availability and quality of data. The findings of this review suggest that the scheduling approach is to be preferred to modeling travel time reliability and should be used whenever possible. However, when the data on the travel time arrivals is not available or the analysis only calls for sketch planning estimates of travel time reliability the use of the mean-variance can be accepted as an alternative.

Both the mean-variance and the scheduling approach rely on quantitative methods describing the distribution of travel times. These measures, which locate the center and spread of a travel time distribution, are necessary to analyze and measure travel time reliability. These metrics capture different aspects of travel time reliability with measures that are dependent on the definition of reliability.

\section{Statistical Range Estimates}

Statistical range estimates use the standard deviation and the coefficient of variation to describe the range of transportation conditions experienced by travelers. Standard deviation (SD) is defined as the root-mean-square deviation of sample values and serves as a measure of 
dispersion. SD measures the extent of dispersion of individual travel times around the mean travel time for a particular route and is computed as

$$
S D=\sqrt{\left(\frac{1}{N} \sum_{i=1}^{N}\left(x_{i}-\bar{x}\right)^{2}\right)}
$$

where $x_{i}$ is the observed arrival travel time of trip $i ; \bar{x}$ is the sample mean of arrival times; and $N$ is the total number of observations.

The coefficient of variation (CV) provides a normalized measure of dispersion of the variable and is defined as the ratio of the standard deviation to the mean

$$
C V=\frac{S D}{\mu}
$$

where $\mu$ is the sample mean of travel times

A high CV value indicates higher variability and therefore increased uncertainty in travel times.

These indicators may not be particularly accurate when the distribution is skewed. This situation occurs in the presence of outliers, or observations that abnormally differ from the mean values (e.g., in the presence of measurement errors). Thus, it is suggested that estimating travel time reliability should be based on the deviation from the median rather than the mean (Tilahun and Levinson, 2006). The median is a measure of centrality of a distribution and is not affected by the presence of outliers. The use of the median is also justified on the premise that travelers usually base their decisions on the most frequently experienced travel time. Thus modal travel time plays a more important role for travel time decisions than mean travel time.

When travel time distribution is not symmetric, both the width and the skew of the travel time distribution can provide a more robust estimate of reliability (Lint and Zuylen, 2005). A variation of buffer time index takes into account distributional skewness, $\lambda_{\text {skew }}$. It is suggested that the skew of the distribution can be measured as the ratio of the difference between the $90^{\text {th }}$ and $50^{\text {th }}$ percentile to the difference between the $50^{\text {th }}$ and $10^{\text {th }}$ percentile

$$
\lambda_{\text {skew }}=\frac{P_{90}-P_{50}}{P_{50}-P_{10}}
$$

where $P_{90}$ denotes the observed $90^{\text {th }}$ percentile, $P_{50}$ the observed $50^{\text {th }}$ percentile value, and $P_{10}$ the observed $10^{\text {th }}$ percentile. This measure differs from the well known statistical definition of skewness (NIST, 2009), which, as argued by Lint et al. (2008), is relatively sensitive to outliers.

The width, $\lambda_{\text {width }}$, can be measured using the difference between the duration of the $90^{\text {th }}$ percentile trip and the duration of the $50^{\text {th }}$ percentile trip (median duration). $\lambda_{\text {width }}$ is the ratio 
between that difference and the duration of the $50^{\text {th }}$ percentile trip itself (Lint and Zuylen, 2005)

$$
\lambda_{\text {width }}=\frac{P_{90}-P_{50}}{P_{50}}
$$

Large values indicate unreliability in travel time. Since both metrics are computed as relative ratios they can be compared across various trips, regardless of the absolute magnitude of travel times. While these parameters are calculated using relatively simple statistical formulas, they are also not very intuitive for a non-technical person and, thus, are not widely accepted as appropriate measures of travel time reliability.

\section{Other Measures}

There are other measures of travel time reliability that are either used as system performance indicators or to communicate network reliability to targeted travelers. These are defined as buffer-time measures and quantify the amount of additional time that must be budgeted by travelers to reach their destinations.

\section{Planning Time Index}

The planning time index represents the total travel time that should be planned for the trip when an adequate buffer time is included. The planning time index compares near-to-worst case travel time to a travel time in free-flow traffic, thus accounting for both typical delay as well as unexpected delay

$$
\text { Planning Time Index }=\frac{95^{\text {th }} \text { travel }_{t t}}{\text { free flow } \text { travel }_{t t}}
$$

For example, a planning time index of 1.5 means that, for a 10 minute trip in free-flow traffic, the total time that should be planned for the trip to guarantee on-time arrival 95 percent of the time is 15 minutes ( 10 minutes x $1.5=15$ minutes).

The frequency that congestion exceeds some expected threshold is typically expressed as the percent of days or time that travel times exceed a certain amount of minutes or that travel speed falls below a given threshold. Calculating this measure of congestion requires the collection of traffic data over several time periods. The above four measures of travel time reliability are recommended for use by FHWA because they are relatively easy to compute and easy to understand by a non-technical person (FHWA, 2006).

11

Center for Urban Transportation Research | National Center for Transit Research 


\section{Buffer Index}

This measure is expressed using an index measuring the additional time that travelers add to their average travel time when planning trips. This index accounts for unexpected delays and is computed as

$$
\text { Buffer Index }(\%)=\frac{95^{\text {th }} \text { travel }_{t t}-\text { mean }_{t t}}{\text { mean }_{t t}}
$$

where rravel $_{t t}$ is $95^{\text {th }}$ percentile travel time, and mean $t t$ is the average travel time.

The use of the above index can be demonstrated by the following example. If, on average, it takes 20 minutes to make a certain trip and only 5 percent of the travelers taking that trip experience travel time longer than 25 minutes, then the buffer index for that trip will be equal to 25 percent (Buffer index $=(25-20) / 20=25 \%$ ). This means that, in order to be on-time 95 percent of the time, travelers will have to dedicate 25 percent more time for taking the trip, compared to the average travel time of that trip. Since this measure is valued in relative units (in percentages) it can be applied to trips of different lengths. In other words, this is not a tripspecific parameter. Therefore, it can be applied to measuring and comparing reliability across the trips of different length.

\section{Tardy-trip Indicators}

Tardy trip indicators use specific thresholds to identify an acceptable late-arrival time, such as the percentage of the trip time, the above-the-average increased amount of time (in minutes) average, or as an absolute value in minutes. These measures use a threshold of unacceptable late arrival time and answer the question "how often will a traveler be unacceptably late?" Several measures of tardy trip indicators are briefly discussed below (Lomax, Schrank and Turner, 2003).

Florida reliability method - an indicator that measures the percentage of trips that arrive ontime or do not exceed an acceptable lateness threshold. Florida is experimenting with four different levels of unacceptable lateness threshold: 5 percent, 10 percent, 15 percent and 20 percent of the average travel time for the evaluated sample of travelers. The formula for calculating Florida reliability statistic is provided below.

Florida Reliability Statistic $=100 \%-\left(\begin{array}{c}\text { percent of trips with travel time } \\ \text { greater than the average for the time } \\ \text { period plus } 5 \%, 10 \%, 15 \% \text { or } \\ 20 \% \text { of the average }\end{array}\right)$ 
Misery index - another tardy trip indicator, shows the average number of minutes that the worst trips exceed the average. The formula for calculating misery index, that compares the average trip to the longest 20 percent of the trips, is provided below.

$$
\text { Misery Index }(M I)=\frac{\left(\begin{array}{c}
\text { Travel time average } \\
\text { for the longest 20\% } \\
\text { of the trips }
\end{array}\right)-\left(\begin{array}{c}
\text { Average travel time } \\
\text { for all trips }
\end{array}\right)}{\text { Average travel time }}
$$

The exact percentage of the "worst trips" used for calculating misery index does not have to be 20 (as in the current example) but can be adjusted to fit specific needs of the analysis.

\section{Probabilistic Approaches}

Probabilistic approaches to measuring travel time reliability are also considered by the literature (Tu, et al., 2005). In this context, reliability is defined as the probability that a certain trip can be made successfully within a specified travel time as a function of route-based density. Density is considered an indicator of traffic condition and is defined as the number of vehicles occupying a given corridor or lane length. The advantage of treating travel time reliability as a density function is that density at a particular road segment can be monitored and reported automatically allowing for real-time estimation of travel time reliability (Tu, Lint and Zuylen, 2005). However, the drawback of defining travel time reliability as a probability density function is that it does not permit monetizing the value of reliability. In addition, very little is known about how travelers perceive reliability and to what extent a subjective probability distribution exists, as well as its relationship to the actual objective distribution (Noland and Polak, 2002).

\section{Suggested Travel Time Reliability Measure}

In conclusion, this review emphasizes the importance of recognizing that part of variation in travel time experienced by the users occurs due to explainable and regular factors that can be expected. The causes for variation in travel time range from predictable factors, such as work zones, special events and weather, to the unpredictable ones - collisions, vehicle breakdowns, as well as the causes that can be characterized as systemic - regular daily traffic volume changes, traffic operation equipment variations, etc. (Lomax, Schrank and Turner, 2003). From a policy perspective it is important to be able to capture not only the total variability (that is experienced by users), but also to distinguish between the contribution of each factor to the total variability of travel time in order to design an effective policy.

All relevant empirical work on the value of travel time reliability as a percentage (or a fraction)

of the value of time herein reviewed relies on the use of distributional ranges, such as the 
difference between the $90^{\text {th }}$ and $50^{\text {th }}$ percentile travel times. These studies generally assume that observed travel times are drawn from a distribution that travelers know from experience. By asserting that travelers care about trip time and reliability, it can be maintained that they consider both the central tendency and the dispersion of this distribution. As suggested by Brownstone and Small (2003), the difference between the $90^{\text {th }}$ and $50^{\text {th }}$ percentile travel times has the advantage of being more closely related to travelers' aversion to the chance of being substantially later than expected. This measure relies on the upper tail distribution of travel times. In these studies, the observed $90^{\text {th }}$ and $50^{\text {th }}$ percentile travel times are computed upon a given network segment and need not to be normalized by travelers' overall trip lengths. For example, in Small, Winston and Yan (2002) and Brownstone and Small (2003), the travelers' travel time distribution refers to observed travel times for 438 individuals traveling over the ten mile section of SR91 in Orange County, California.

For the purpose of this synthesis, the use of the above ranges is suggested as an approach to measure travel time reliability. This measure is relatively easy to obtain and does not necessarily rely on specific assumptions about the shape of the travel time distribution (e.g., it can apply to lognormal or normal distributions). In the presence of data that are too sparse to determine the $95^{\text {th }}$ percentile, the $90^{\text {th }}-50^{\text {th }}$ or the $80^{\text {th }}-50^{\text {th }}$ percentile can also be used (Small, et al., 2005). This measure is to be used to quantify reliability on a given segment of a network or to measure reliability assuming travelers engage in trips of equal length. To compare trips of different lengths, it is suggested to normalize the difference between the $90^{\text {th }}$ and $50^{\text {th }}$ percentile travel times by dividing it by the median travel time. The choice of median travel time above mean travel time is to be preferred in the presence of outliers. A summary of theoretical research on the issues of modeling and estimating the value of travel time and travel time reliability is presented in Appendix $A$.

\subsection{Review of Empirical Models}

This section summarizes empirical findings and estimates of the value of time and the value of reliability of travel time. Appendix B provides a more extended review in tabular format.

\subsubsection{Empirical estimates of the value of time}

The studies herein reviewed show that personal travel time unit costs are usually estimated at 25 to 50 percent of the prevailing average wage rate, depending on multiple factors, including demographics of the travelers and characteristics of the trip. Travel time costs tend to be higher for uncomfortable, unsafe and stressful conditions. Early work on the value of time produced larger estimates ranging from 30 to 50 percent of the average wage(Becker, 1965, Beesley, 1965, Lisco, 1967). 
Surveys of route choice models yield an average value of travel time of about 60 percent of the gross wage, with ranges from 20 to 100 percent among industrialized cities (Calfee and Winston, 1998, Miller, 1989, Small, 1982).

In particular, using a stated-preference approach, Calfee and Winston (Calfee and Winston, 1998) found commuters' average willingness to pay to reduce travel time ranging from 14 to 26 percent of the gross wage with an average of 19 percent for the entire sample and all scenarios. This study also found the value of travel time to be insensitive to travel conditions. Calfee and Winston explain these lower estimates on the fact that commuters are able to adjust to congestion through their modal and departure time choices, as well as the choice of residential and workplace location.

The value of travel time usually differs substantially between different travelers. In most cases travelers' valuation of time is considerably higher when measured in real rather than hypothetical scenarios (the analysis of revealed preferences vs. stated preferences). A recent revealed preference study of commuters in the Los Angeles area by Small et al., $(2001,2005)$ estimates the median value of time at 93 percent of the average wage rate $(\$ 21.46 /$ hour $)$, and the median value of reliability at roughly 85 percent of the average wage rate $(\$ 19.56 /$ hour $)$ (Small, Winston and Yan, 2005).

The U.S. Department of Transportation (USDOT) suggests various travel time values to be used in evaluating transportation projects. These travel time values vary from 50 to 120 percent of the wage rate, depending on the length and the type of travel (business versus personal), but they fail to account for qualitative factors such as travel comfort or reliability (USDOT, 2003). USDOT recommends the following values of travel time savings to be used in the economic analysis studies of surface transportation: $\$ 10.60 /$ hour for personal local travel, $\$ 21.20 /$ hour for business travel, and $\$ 11.20 /$ hour for all purposes travel, measured in year 2000 dollars (USDOT, 2003).

Researchers have developed empirical travel time estimates that account for various qualitative factors, including type of travel (commercial vs. personal), type of traveler (driver, adult passenger, child passenger), transportation mode (automobile, bus, bicycle, walk), and travel condition (measured by the level-of-service). Waters (Waters, 1992), for example, suggests that personal in-vehicle travel time valuation can vary from 50 percent, at the best level-ofservice rating (A rating), to 100 percent of the wage for the worst rating ( $F$ rating). Waters also recommends that commercial vehicle travel time should be valued at 120 percent and 170 percent of wage rate for the best and worst LOS rating respectively.

The empirical estimates of VOT, found in the reviewed travel time studies, are summarized in Table 1.

15

Center for Urban Transportation Research | National Center for Transit Research 
TABLE 1 Empirical Estimates of VOT

\begin{tabular}{|c|c|c|}
\hline Study & Data Used & VOT Estimate \\
\hline (Becker, 1965) & & $40 \%$ of wage rate \\
\hline (Beesley, 1965) & $\begin{array}{l}\text { Data from the survey of government } \\
\text { employees in London, UK }\end{array}$ & $31 \%-50 \%$ of wage rate \\
\hline (Lisco, 1967) & & $20 \%-51 \%$ of wage rate \\
\hline (Miller, 1989) & $\begin{array}{l}\text { Survey of multiple route choice } \\
\text { models }\end{array}$ & $60 \%$ of gross wage (on average) \\
\hline (Small, 1992) & $\begin{array}{l}\text { Values derived from multiple mode } \\
\text { choice transportation models }\end{array}$ & $\begin{array}{l}20 \% \text { to } 100 \% \text { of gross wage; } 50 \% \text { - } \\
\text { reasonable average }\end{array}$ \\
\hline (Waters, 1992) & $\begin{array}{l}\text { Travel data from British Columbia, } \\
\text { Canada }\end{array}$ & $\begin{array}{l}50 \%-100 \% \text { average wage rate for } \\
\text { personal travel, depending on LOS; } \\
120 \%-170 \% \text { of average wage rate } \\
\text { for commercial travel, depending on } \\
\text { LOS }\end{array}$ \\
\hline (Waters, 1996) & $\begin{array}{l}\text { Travel data from } 15 \text { commuting } \\
\text { studies in North America }\end{array}$ & $\begin{array}{l}40 \%-50 \% \text { of after tax wage rate } \\
\text { (mean: } 59 \% \text { of after tax wage rate; } \\
\text { median: } 42 \% \text { of wage rate) }\end{array}$ \\
\hline (Calfee and Winston, 1998) & $\begin{array}{l}\text { Data from National Family Opinion } \\
\text { survey, covering commuters from } \\
\text { major U.S. metropolitan areas }\end{array}$ & $\begin{array}{l}14 \%-26 \% \text { of gross wage; } 19 \% \text { of } \\
\text { wage - average estimate }\end{array}$ \\
\hline (Small and Yan, 2001) & $\begin{array}{l}\text { Data on commute travelers on SR- } \\
91 \text { in California }\end{array}$ & $\begin{array}{l}\text { Average VOT is } \$ 22.87 / \text { hour, or } 72 \% \\
\text { of sample wage rate }\end{array}$ \\
\hline (Brownstone and Small, 2003) & $\begin{array}{l}\text { Travel data from ETC facilities in } \\
\text { HOT lanes on SR-91 and I-15 in } \\
\text { Southern California }\end{array}$ & $\begin{array}{l}\text { VOT saved on the morning } \\
\text { commute: } \$ 20-\$ 40 \text { per hour, or } \\
50 \%-90 \% \text { of average wage rate in } \\
\text { the sample }\end{array}$ \\
\hline (USDOT, 2003) & $\begin{array}{l}\text { Estimates are based on multiple } \\
\text { sources of data }\end{array}$ & $\begin{array}{l}50 \%-120 \% \text { of the wage rate } \\
\text { depending on type of travel } \\
\text { (personal vs. business); } \\
50 \% \text { of wage rate for personal local } \\
\text { travel } \\
100 \% \text { of wage rate for commercial } \\
\text { local travel }\end{array}$ \\
\hline (Small, Winston and Yan, 2005) & $\begin{array}{l}\text { Travel from SR-91 in greater Los } \\
\text { Angeles area (CA), collected over } \\
\text { 10-month period in } 1999-2000\end{array}$ & $\begin{array}{l}\text { Median VOT is } \$ 21.46 / \text { hour or } 93 \% \\
\text { of average wage rate }\end{array}$ \\
\hline (Tseng, Ubbels and Verhoef, 2005) & $\begin{array}{l}\text { Data for Dutch commuters who } \\
\text { drive to work two or more times per } \\
\text { week. Collected in June } 2004\end{array}$ & $\begin{array}{l}\text { Mean VOT for all travelers: } 10 \\
\text { Euros/hour (approximately } \\
\$ 12.10 / \text { hour) }\end{array}$ \\
\hline (Litman, 2007) & Results are drawn from multiple & $25 \%-50 \%$ of prevailing wage (for \\
\hline
\end{tabular}




\begin{tabular}{lll}
\hline \multicolumn{1}{c}{ Study } & \multicolumn{1}{c}{ Data Used } & \multicolumn{1}{c}{ VOT Estimate } \\
\hline & travel time studies & personal travel) \\
(Tilahun and Levinson, 2007) & $\begin{array}{l}\text { Data from stated preference survey } \\
\text { of travelers on I-394, in } \\
\text { Minneapolis/St. Paul area }\end{array}$ & $\begin{array}{l}\$ 10.62 / \text { hour for MnPass (ETC } \\
\text { system) subscribers that were } \\
\text { early/on-time }\end{array}$ \\
& $\begin{array}{l}\text { \$25.42/hour for MnPass subscribers } \\
\text { that were late }\end{array}$ \\
& $\begin{array}{l}\text { \$13.63/hour for non-subscribers } \\
\text { that were early/on-time }\end{array}$ \\
& $\$ 10.10 /$ hour for non-subscribers \\
& that were late
\end{tabular}

\subsubsection{Empirical Measures of the Value of Travel Time Reliability}

Although assessing the value of travel time reliability is not as common as assessing the value of time, this practice is gaining momentum. Since 1994, a series of U.S. congestion pricing demonstration projects provided valuable empirical evidence. Stated preference and revealed preference experiments conducted on California, Texas, and Minnesota provided insight into the evaluation of travelers' willingness to pay to reduce commute and variability of travel times. In quantifying the value of reliability researchers often examine the tradeoff between travel time reliability and value of time. Expected utility theory suggests that a risk-averse traveler would be willing to pay a monetary sum to decrease travel time uncertainty.

Various empirical studies estimate the value of travel time reliability ranging from 0.55 to 0.70 (Black and Towriss, 1993), to 3.22 times the value of travel time (Small, et al., 1999). Recent work, however, finds that travelers value improvement in reliability very close to reducing travel time, making the value of reliability comparable to the value of travel time (Tilahun and Levinson, 2006). In the first two studies, reliability is measured by the standard deviation. Tilahun and Levinson (Tilahun and Levinson, 2006), however, experimented with three measures of reliability: 1) probability of early or late arrivals compared to usual travel time, 2) right range of travel time distribution (the difference between 100-th and 50-th percentiles), or the probability of exceeding a certain lateness threshold (5 minutes late compared to mode travel time), 3) standard deviation. All three approaches yielded similar results.

In road pricing demonstrations of SR-91 and I-15, California, the value of travel time reliability was estimated to be between 95 to 140 percent of the median travel time value (Brownstone 
and Small, 2003). Defined as the difference between the $90^{\text {th }}$ and $50^{\text {th }}$ percentile, reliability accounted for one third of the service quality differential between free and express lanes.

Measuring reliability as the difference between the $75^{\text {th }}$ and $25^{\text {th }}$ percentile travel times, a revealed-preference study of commuters in the Los Angeles area estimated the median value of reliability at roughly 85 percent of the average wage rate $(\$ 19.56 /$ hour) (Small, Winston and Yan, 2005).

These demonstrations show that transportation policies affecting travel time reliability can yield user benefits comparable to or exceeding the benefits realized through roadway capacity expansion.

There is evidence that socio-economic factors have influence on how reliability is valued. In a recent study, Small et al. (2005) found women, middle-aged motorists, and motorists in smaller households are more likely to use tolled lanes, indicating that these categories of commuters are more averse to unreliability (possibly, due to fixed schedules) than the average traveler

A stated preference study of Dutch commuters also indicates that certain socio-economic factors and the presence of arrival/departure time restrictions influence the way reliability is valued by travelers (Tseng, Ubbels and Verhoef, 2005). For example, the study finds that lower income groups, more than others, tend to dislike variability and thus value travel time reliability higher. While arriving late generally causes larger disutility than arriving early, the tolerance to arriving early decreases non-linearly (while people can tolerate a certain extent of early arrivals they do not like to arrive too early) (Tseng, Ubbels and Verhoef, 2005). This study defines reliability in terms of the deviation of the actual arrival time from preferred arrival time for each trip, with late and early arrivals modeled separately.

These findings imply that, even in the areas with low prevailing wage rate, road value pricing can be successful if the travelers highly value the reliability of their travel time (as provided by tolled lanes).

There is also evidence that the value of reliability varies with the purpose of the trip. A recent stated preference study of French rail commuters indicated that people dislike arriving late at their work destinations more than arriving late to other purpose destinations (Kouwnhoven, et al., 2006). These findings also indicate that there might be a certain degree of substitutability between comfort and reliability of travel. This assumption, however, needs further examination.

Finally, some research finds that the disutility from additional delays decreases as the severity of delays increases. A study of Paris rail commuters indicates that the disutility from the first delayed train is the highest, and the extra disutility decreases with each additional train being 
delayed (Kouwnhoven, Caussade and Kroes, 2006). For practitioners this can mean that improving reliability may yield higher marginal benefits (in terms of increased utility) when the level of unexpected delay is relatively low (i.e., when reliability is rather high).

Overall, empirical estimation of how travelers react to changes in travel time variability have mirrored the two analytical approaches (mean-variance and scheduling approach) discussed earlier in this report. Early studies made use of the standard deviation, while more recent studies shift focus to the scheduling costs associated with variability. Empirical estimates of the value of travel time reliability are summarized in Table 2 .

19

Center for Urban Transportation Research | National Center for Transit Research 
TABLE 2 Empirical Estimates of VOR

\begin{tabular}{|c|c|c|c|}
\hline Study & Data Used & VOR Estimate & Definition of Reliability \\
\hline $\begin{array}{l}\text { (Brownstone and Small, } \\
\text { 2003) }\end{array}$ & $\begin{array}{l}\text { Travel data from ETC } \\
\text { facilities in HOT lanes } \\
\text { on SR-91 and I-15 in } \\
\text { Southern California, } \\
\text { 1996-2000 }\end{array}$ & $\begin{array}{l}95 \%-140 \% \text { of the } \\
\text { median travel time }\end{array}$ & $\begin{array}{l}\text { Difference between } 90- \\
\text { th and } 50 \text {-th percentile } \\
\text { travel time }\end{array}$ \\
\hline $\begin{array}{l}\text { (Small, Winston and } \\
\text { Yan, 2005) }\end{array}$ & $\begin{array}{l}\text { Travel data from SR-91 } \\
\text { in greater Los Angeles } \\
\text { area, 1999-2000 }\end{array}$ & $\begin{array}{l}\text { VOR estimated at } \\
\$ 19.56 / \text { hour, or } 85 \% \text { of } \\
\text { average wage rate }\end{array}$ & $\begin{array}{l}\text { Difference between } 75- \\
\text { th and } 25 \text {-th percentile } \\
\text { travel time }\end{array}$ \\
\hline $\begin{array}{l}\text { (Black and Towriss, } \\
\text { 1993) }\end{array}$ & $\begin{array}{l}\text { Data from SP survey of } \\
\text { travelers in London }\end{array}$ & $0.55-0.70$ of travel time & $\begin{array}{l}\text { Measured as standard } \\
\text { deviation of travel time }\end{array}$ \\
\hline $\begin{array}{l}\text { (Small, Noland, Chu and } \\
\text { Lewis, 1999) }\end{array}$ & $\begin{array}{l}\text { SP survey of travelers in } \\
\text { SR-91 corridor in } \\
\text { Orange and Riverside } \\
\text { counties in Southern } \\
\text { California, conducted in } \\
1995\end{array}$ & $\begin{array}{l}\text { Average of } 2.37 \text { of } \\
\text { travel time for median } \\
\text { income and all trips } \\
\text { (\$12.60/hour) } \\
\text { Greater than } 3 \text { times of } \\
\text { travel time for work } \\
\text { trips and higher income }\end{array}$ & $\begin{array}{l}\text { Reliability is measured } \\
\text { by standard deviation of } \\
\text { travel time }\end{array}$ \\
\hline $\begin{array}{l}\text { (Tilahun and Levinson, } \\
\text { 2007) }\end{array}$ & $\begin{array}{l}\text { Data from a SP route } \\
\text { choice survey of } \\
\text { University of Minnesota } \\
\text { employees, } \\
\text { Minneapolis/St. Paul, } \\
\text { MN }\end{array}$ & Equivalent to VOT & $\begin{array}{l}\text { Difference between } \\
\text { actual late arrival and } \\
\text { usual (mode) travel } \\
\text { time }\end{array}$ \\
\hline $\begin{array}{l}\text { (Tseng, Ubbels and } \\
\text { Verhoef, 2005) }\end{array}$ & $\begin{array}{l}\text { Data from surveying } \\
\text { Dutch commuters, } 2004\end{array}$ & $\begin{array}{l}\text { VOR is valued at } 1 / 2 \text { of } \\
\text { the VOT }(5.3 \\
\text { Euros/hour, or } \\
\$ 6.41 / \text { hour)* }\end{array}$ & $\begin{array}{l}\text { Difference between } \\
\text { early /late arrival time } \\
\text { and preferred arrival } \\
\text { time. Early and late } \\
\text { arrivals are modeled } \\
\text { separately. }\end{array}$ \\
\hline
\end{tabular}

* The conversion is based on exchange rate of 1 Euro $=1.21$ USD, which was average rate for June 2004, when the analysis was conducted 


\section{Findings}

\subsection{Value of Time}

The literature review of the theoretical models found that there is no unique definition of the value of time. Classical microeconomic theory of time allocation defines the value of time as the opportunity cost of an additional unit of leisure, i.e., the hourly wage rate. This theory does not explicitly consider that the purchase of goods and services also requires time consumption. Thus, the definition hinges on the assumption of minimum-time constraints that require individuals to travel in order to purchase goods and services (DeSerpa, 1971). The explicit inclusion of minimum time requirements and discretionary time allocations potentially leads to different marginal values of time (Palmquist, Phaneuf and Smith, 2007).

The use of the average wage rate to estimate the opportunity cost of time is just an approximation to the value of time. This problem arises because the marginal wage, representing the true opportunity cost of time, is not directly observable. Both theoretical and empirical research indicates that the value of time can be significantly higher or lower than the current wage rate, depending on the activities people are involved in (Jara-Diaz, 2002). Many factors can affect the value consumers attach to their time; trip purpose, socio-demographic characteristics (e.g., marital status), working schedule flexibility, are among the most cited ones.

Other factors related to study design and data measurement problems affect empirical estimation. For example, travelers often tend to overstate congestion-related delays and understate the benefits from saving travel time. This can lead to the differences in travel time estimates obtained from empirical studies based on stated preferences (hypothetical scenarios) and revealed preferences (observed behavior).

\subsection{Value of Reliability of Travel Time}

Although assessing the value of travel time reliability is not as common as assessing the value of time, this practice is gaining momentum. In quantifying the value of reliability researchers often examine the tradeoff between travel time reliability and value of time. Theory suggests that a risk-averse traveler would be willing to pay a monetary sum to decrease travel time uncertainty or willing to accept longer but more reliable travel times.

The findings of this review indicate that travelers value reliability as much as travel time savings. For policy makers, this can mean that transportation improvement projects that

21

Center for Urban Transportation Research | National Center for Transit Research 
improve travel time reliability (not only travel time) can generate significant benefits to travelers. These findings imply that, even in the areas with low prevailing wage rate, road value pricing can be successful if the travelers highly value the reliability of their travel time (as provided by tolled lanes). These findings also indicate that there might be a certain degree of substitutability between comfort and reliability of travel. This assumption, however, needs further examination.

\subsection{Guidelines and Suggestions}

Both the value of time and the value of reliability have many dimensions and can be affected by various factors. Accounting for all those factors may not always be feasible or economically practical. However, empirical estimates can be used in assessing the value of time and reliability as long as they are used and interpreted with caution.

\subsubsection{Value of Travel Time}

Estimates of the value of travel time vary substantially. However, the attempt was made to reconcile the existing valuation differences and provide useful guidelines for practitioners. The following values can be considered as reasonable estimates of travel time:

- Personal travel time (including commute travel) should be valued at 50 percent of prevailing wage rate

- On-the-clock paid travel (e.g., commercial vehicle driver) should be valued at 100 percent of the driver's wages plus benefits

- Transit travel time should be valued at 25-35 percent of prevailing wage under comfortable conditions (when sitting), but can be significantly higher for crowded transit vehicles (100\% of wage rate) or for waiting under unpleasant conditions (up to $175 \%$ of wage rate).

- The use the national average wage rate is recommended as a basis for determining the value of time, unless reliable information on the earnings of particular users of a transportation facility is available and these earnings are significantly different from the national average.

National wage rate statistics, as provided by the Bureau of Labor Statistics, can be used. The use of national averages permits comparing projects in different geographic areas. The recommended values of travel time are summarized in Table 3.

22

Center for Urban Transportation Research | National Center for Transit Research 
TABLE 3 Recommended Values of Travel Time

Personal travel time

Commercial (on-the-clock) travel time

Transit travel time:

- When sitting

- When standing

- In crowded transit vehicle

- Waiting under unpleasant conditions
$50 \%$ of wage rate

$100 \%$ of wage rate plus benefits

$25 \%-35 \%$ of wage rate

$50 \%$ of wage rate

$100 \%$ of wage rate

Up to $175 \%$ of wage rate

\subsubsection{Reliability of Travel Time}

The findings of this review confirm that the scheduling approach is preferred for modeling travel time reliability and should be used whenever possible. However, when the data on the travel time arrivals is not available or the analysis only calls for sketch planning estimates of travel time reliability the use of the mean-variance can be accepted as an alternative.

The $95^{\text {th }}-50^{\text {th }}$ range measurement of travelers' travel time distribution is suggested as an approach to measure travel time reliability. This measure is relatively easy to obtain and does not necessarily rely on specific assumptions about the shape of the travel time distribution (e.g., it can apply to lognormal or normal distributions). This measure is to be used to quantify reliability on a given segment of a network or to measure reliability assuming travelers engage in trips of equal length. To compare trips of different lengths, it is suggested to normalize the difference between the $90^{\text {th }}$ and $50^{\text {th }}$ percentile travel times by dividing it by the median travel time. The choice of median travel time above mean travel time is to be preferred in the presence of outliers. In the presence of data that are too sparse to determine the $95^{\text {th }}$ percentile, the $90^{\text {th }}-50^{\text {th }}$ or the $80^{\text {th }}-50^{\text {th }}$ percentile can also be used (Small, Winston and Yan, 2005).

The empirical findings on the value of reliability of travel time provide mixed and often conflicting evidence. Ultimately, the choice of the approach to model travel time variability is determined by the purposes of the analysis and the availability and quality of data. The review suggests that the following factors are to be taken into account when using the recommendations of Table 4:

- Reliability is valued close to the value of travel time 
- In the case of non-flexible arrival/departure constraints (e.g., fixed work schedules) the value of reliability can increase up to three times that of the in-vehicle travel time

- Risk-averse travelers may be willing to trade travel time duration (or willing to travel longer) for reduced variability

- Trip purpose can impact the value of reliability of travel time; leisure travelers typically value reliability lower than people traveling for commute purposes

- Demographic and socio-economic factors, such as age, gender, and income can influence how travelers value reliability

- For short delays, tolerance to arriving early is decreasing non-linearly (i.e., value of travel time reliability is increasing exponentially with increased variability of travel time).

- For longer delays, marginal disutility from delay decreases as the delay becomes more severe (i.e., value of reliability decreases as variability of travel increases).

TABLE 4 Recommended Value of Travel Time Reliability (VOR)

\begin{tabular}{ll}
\hline \multicolumn{1}{c}{ Circumstances } & VOR \\
\hline Ordinary circumstances, no major constraints & $80 \%$ to $100 \%$ of VOT \\
Presence of non-flexible arrival/departure constraint & Valued at up to 3 times of VOT \\
\hline
\end{tabular}




\section{Conclusions}

This study compiles extensive research into an application-oriented document to provide practitioners with applicable ranges of estimates of the value of time (VOT). This work also culls the more limited research on the value of time reliability (VOR).

The review of theoretical empirical literature attempts to clarify the complex issues of defining, modeling, and measuring VOT and VOR. Different theoretical approaches to defining VOT and VOR are discussed and an attempt is made to reconcile the existing differences. The complexities of VOT and VOR are revealed and estimation issues are summarized.

This report also provides an overview of the most cited empirical estimates of VOT and VOR. The discussion of empirical research is followed by a summary of estimates obtained from relevant studies, which are then reported in a concise tabular format.

In separate appendices, tables summarizing the main results of the theoretical and empirical studies of VOT and VOR are presented. These tables cover the vast body of research reviewed in this synthesis and are intended to serve as a quick reference for practitioners and policy makers.

The current synthesis is intended to serve as a reference for practitioners. The comprehensive but concise summary of previous research, as well as the referenced values of VOT and VOR, will be valuable to practitioners for use as estimates in project evaluations.

The literature is in continuous evolution with recent efforts aimed at presenting unified frameworks of analysis that explicitly account for this minimum-time constraint, and allow for the trade-off between discretionary and mandatory travel. Additional work is required to understand how travelers react to changes in travel time distributions, and to what extent subjective distributions affect travelers' decisions. Continuing research in these areas is warranted to create effective road pricing policies.

25

Center for Urban Transportation Research | National Center for Transit Research 
[This page intentionally left blank.] 


\section{References}

Booz-Allen \& Hamilton, Inc. 1998. "1998 California Transportation Plan: Transportation System Performance Measures: Final Report," Sacramento, CA: California Department of Transportation, Booz-Allen \& Hamilton, Inc

Texas Transportation Institute. 2003. "Mobility Monitoring Program," Texas Transportation Institute, Texas Transportation Institute

National Cooperative Highway Research Program. 1998. "Multimodal Corridor and Capacity Analysis Manual," Washington, DC: National Research Council Transportation Research Board, National Cooperative Highway Research Program

AASHTO. 2000. "Transportation Invest in America, the Bottom Line," American Association of State Highway and Transportation Officials,

Algers, Staffan, Pål Bergström, Matz Dahlberg and Johanna Lindqvist Dillén. 1998. "Mixed Logit Estimation of the Value of Travel Time," Uppsala, Sweden: Uppsala University, Department of Economics

Anas, Alex. 2007. "A Unified Theory of Consumption, Travel and Trip Chaining," Journal of Urban Economics, 62, 162-186.

Anas, Alex and Ikki Kim. 1996. "General Equilibrium Model of Polycentric Urban Land Use with Endogenous Congestion and Job Agglomeration," Journal of Urban Economics, 232-256.

Anas, Alex and Rong Xu. 1999. "Congestion, Land Use, and Job Dispersion: A General Equilibrium Model," Journal of Urban Economics, 451-473.

Bargain, Olivier. 2007. "On Modeling Household Labor Supply with Taxation," Dublin: School Of Economics, University College Dublin

Bates, John, John Polak, Peter Jones and Andrew Cook. 2001. "The Valuation of Reliability for Personal Travel," Transportation Research Part E, 37, 191-229.

Becker, Gary S. 1965. "A Theory of the Allocation of Time," The Economic Journal, 75, 493-517.

Beesley, M. E. 1965. "The Value of Time in Travelling: Some New Evidence," Economica, 32, 174-185. 
Ben-Akiva, Moshe and John L. Bowman. 1998. "Integration of an Activity-Based Model System and a Residential Location Model," Urban Studies, 35, 1131-1153.

Bhat, Chandra R. and Frank S. Koppelman. 1999. "A Retrospective and Prospective Survey of Time-Use Research," Transportation, 26, 119-139.

Bhat, Chandra R. and Rajul Misra. 1999. "Discretionary Activity Time Allocation of Individuals between in-Home and out-of-Home and between Weekdays and Weekends," Transportation, 26, 193-209.

Black, I. G. and J. G. Towriss. 1993. "Demand Effects of Travel Time Reliability," Centre for logistics and transportation, Cranfield Institute of Technology

Borgers, Aloys and Harry Timmermans. 1993. "Transport Facilities and Residential Choice Behavior: A Model of Multi-Person Choice Processes," The Journal of the Regional Science Association International, 72, 45-61.

Brownstone, David and Kenneth A. Small. 2003. "Valuing Time and Reliability: Assessing the Evidence from Road Pricing Demonstrations," Transportation Research Part A: Policy and Practice, 39, 279-293.

Calfee, John and Clifford Winston. 1998. "The Value of Automobile Travel Time: Implications for Congestion Policy," Journal of Public Economics, 83-102.

Clark, William A.V., Youqin Huang and Suzanne Withers. 2003. "Does Commuting Distance Matter? Commuting Tolerance and Residential Change," Regional Science and Urban Economics, 33, 199-221.

Cohan, Harry and Frank Southworth. 1999. "On the Measurement and Valuation of Travel Time Variability Due to Incidents on Freeways " Journal of Transportation and Statistics, 2, 123131.

DeSerpa, Allan C. 1975. "On the Comparative Statics of Time Allocation Theory "The Canadian Journal of Economics, 8, 101-111.

- - 1971. "A Theory of the Economics of Time," The Economic Journal, 81, 828-846

Florida Department of Transportation. Elefteriadou, L and X Cui. 2007. "Travel Time Reliability and Truck Level of Service on the Strategic Intermodal System," Tallahassee, FL: Florida Department of Transportation, Florida Department of Transportation 
FDOT. 2000. "The Florida Reliability Method in Florida's Mobility Performance Measures Program," Tallahassee, FL: Florida Department of Transportation,

FHWA. 2006. "Travel Time Reliability: Making It There on Time, All the Time," US Department of Transportation Federal Highway Administration,

Gronau, Reuben. 1976. "Economic Approach to Value of Time and Transportation Choice " Value of Travel Time, Transportation Research Record 587, 1-5.

- - 1977. "Leisure, Home Production, and Work - the Theory of the Allocation of Time Revisited "The Journal of Political Economy, 85, 1099-1124.

Hensher, David A. 1976. "Review of Studies Leading to Existing Values of Travel Time," Value of Travel Time, Transportation Research Record 587, 30-41.

Hochman, Oded and Haim Ofek. 1977. "The Value of Time in Consumption and Residential Location in an Urban Setting "The American Economic Review, 67, 996-1003.

Hollander, Yaron. 2006. "Direct Versus Indirect Models for the Effects of Unreliability," Transportation Research Part A, 40, 699-711.

Jara-Diaz, Sergio R. 2002. In Perpetual Motion: Travel Behavior Research Opportunities and Application Challenges Elsevier

- - 2003. "On the Goods-Activities Technical Relations in the Time Allocation Theory " Transportation 30, 245-260.

Johnson, M. Bruce. 1966. "Travel Time and the Price of Leisure," Western economic journal, 4, 135-145.

Kockelman, Kara Maria. 2001. "A Model for Time- and Budget-Constrained Activity Demand Analysis," Transportation Research Part B, 35, 255-269.

- - 1998. "A Utility-Theory-Consistent System-of-Demand-Equations Approach to Household Travel Choices," Civil and Environmental Engineering, University of California

RAND Corporation. Kouwnhoven, Marco, Sebastian Caussade and Eric Kroes. 2006. "Value of Reliability of Travellers on the Paris Suburban Railway Network," 1-52, Santa Monica, CA: RAND Corporation

Lam, Terence. 2004. "Evaluating Value-Pricing Projects with Both Scheduling and Route Choices," Regional Science and Urban Economics, 34, 225-240. 
Lancaster, Kevin J. 1966. "A New Approach to Consumer Theory," The Journal of Political Economy, 74, 132-157.

Levinson, David M. 1999. "Space, Money Life-Stage, and the Allocation of Time," Transportation, 26, 141-171.

Lint, J. W. C. van and H. J. van Zuylen. 2005. "Monitoring and Predicting Freeway Travel Time Reliability Using Width and Skew of Day-to-Day Travel Time Distribution," Transportation Recearch Record: Journal of the Transportation Research Board, 1917, 54-62.

Lint, J. W. C. van, H. J. van Zuylen and H Tu. 2008. "Travel Time Unreliability on Freeways: Why Measures Based on Variance Tell Only Half of the Story," Transportation Research Part A, 42, 258-277.

Lisco, T. 1967. "The Value of Commuters' Travel Time. A Study in Urban Transportation," University of Chicago

Victoria Transportation Policy Institute. Litman, Todd. 2007. "Valuing Transit Service Quality Improvements," 1-37, Victoria, BC, Canada: Victoria Transportation Policy Institute

U.S. Department of Transportation Lomax, Tim, David Schrank and Shawn Turner. 2003. "Selecting Travel Reliability Measures," Washington, D.C. : Federal Highway Administration, U.S. Department of Transportation

Lyman, Kate and Robert L. Bertini. 2008. "Using Travel Time Reliability Measures to Improve Regional Transportation Planning and Operations," Transportation Research Record, 2046, 1-10.

Meloni, I., L. Guala and A. Loddo. 2004. "Time Allocation to Discretionary in-Home, out-ofHome Activities and Trips," Transportation, 31, 69-96.

Miller, Ted. 1989. "The Value of Time and the Benefit of Time Saving," Washington, DC.: Urban Institute working paper

Mun, Se-il, Ko-ji Konishi and Kazuhiro Yoshikawa. 2005. "Optimal Cordon Pricing in a NonMonocentric City," Transportation Research Part A, 39, 723-736.

Noland, Robert B. and John W. Polak. 2002. "Travel Time Variability: A Review of Theoretical and Empirical Issues," Transport Reviews, 22, 39-54.

Noland, Robert B., Kenneth A. Small, Pia Maria Koskenoja and Xuehao Chu. 1997. "Simulating Travel Reliability," Regional Science and Urban Economics, 28, 535-564. 
Palmquist, Raymond, Daniel Phaneuf and Kerry Smith. 2007. "Measuring the Value for Time," NBER Working Paper Series, National Bureau of Economic Research (NBER),

Reichman, Shalom. 1976. "Conceptual Problems in Evaluation of Travel Time," Value of Travel Time, Transportation Research Record 24-29.

Reichman, Shalom and Peter R. Stopher. 1976. "Applications of Value of Travel Time to Travel Demend Estimation," Value of Travel Time, Transportation Research Record 587, 6-11.

Shaw, W. Douglass. 1992. "Searching for Opportunity Cost of an Individual's Time," Land Economics, 68, 107-115.

Small, Kenneth. 1982. "The Scheduling of Consumer Activities: Work Trips," American Economic Review, 72, 467-479.

- - 1992. Urban Transportation Economics. Chur, Switzerland: Harwood Academic Publishers

Small, Kenneth A., Clifford Winston and Jia Yan. 2005. "Uncovering the Distribution of Motorists' Preference for Travel Time and Reliability," Econometrica, 73, 1367-1382.

Small, Kenneth A. and Jia Yan. 2001. "The Value of "Value Pricing" of Roads: Second-Best Pricing and Product Differentiation," Journal of Urban Economics, 49, 310-336.

Small, Kenneth, Robert B. Noland, Xuehao Chu and David Lewis. 1999. "Valuation of TravelTime Savings and Predictability in Congested Conditions for Highway User-Cost Estimation," Transportation Research Board, Washington, D.C. : National Cooperative Highway Research Program,

Solberg, Eric J. and David C. Wong. 1992. "Family Time Use: Leisure, Home Production, Market Work, and Work Related Travel," The Journal of Human Resources, 27, 485-510.

Stopher, Peter R. 1976. "Derivation of Values of Time from Travel Demand Models," Value of Travel Time, Transportation Research Record 12-18.

Tilahun, Nebiyou Y. and David M. Levinson. 2006. "A Moment of Time: Reliability in Route Choice Using Stated Preference," Transportation Research Board 87th Annual Meeting, Washington, D.C.

- - 2007. "Value of Time Comparisons in the Presence of Unexpected Delay," Third International Conference on Transport Network Reliability, Delft, Netherlands. 
Tseng, Yin Yen, Barry Ubbels and Erik Verhoef. 2005. "Value of Time, Schedule Delay and Reliability. Estimation Results of a Stated Choice Experiment among Dutch Commuters Facing Congestion," ERSA conference,

Tu, Huizhao, Hans van Lint and Henk van Zuylen. 2005. "Real-Time Modeling Travel Time Reliability on Freeway," 10-th Euro Working Group Transportation Meeting \& 16-Mini-Euro Conference, Poznan, Poland.

USDOT. 2003. "Revised Departmental Guidance: Valuation of Travel Time in Economic Analysis," U.S. Department of Transportation,

Verhoef, Erik T. 2005. "Second-Best Congestion Pricing Schemes in the Monocentric City," Journal of Urban Economics, 58, 367-388.

Waters, William. 1992. "Value of Time Savings for the Economic Evaluation of Highway Investments in British Columbia "Reports and Studies, British Columbia Ministry of Transportation,

--. 1996. "Values of Travel Time Savings in Road Transport Project Evaluation," 7-th World Conference on Transport Research, Oxford, England.

Yamomoto, Toshiyuki and Ryuichi Kitamura. 1999. "An Analysis of Time Allocation to in-Home and out-of-Home Discretionary Activities across Working Days and Non-Working Days," Transportation, 26, 211-230.

Zhang, Junyi, Harry J.P. Timmermans and Aloys Borgers. 2005. "A Model of Household Task Allocation and Time Use," Transportation Research Part B, 81-95. 


\section{Appendix A - Summary Table of Theoretical Work}

\begin{tabular}{|c|c|c|c|}
\hline $\begin{array}{l}\text { zे } \\
\text { मे }\end{array}$ & $\begin{array}{l}\text { Sample size; geographic } \\
\text { scale; data used }\end{array}$ & $\begin{array}{l}\text { Estimation process; } \\
\text { relevant variables }\end{array}$ & Findings \\
\hline 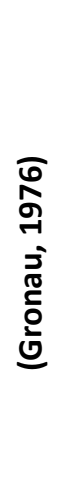 & & $\begin{array}{l}\text { - Maximization of household utility } \\
\text { function subject to budget constraint } \\
\text { and time constraint } \\
\text { - Household production function } \\
\text { allows for joint production } \\
\text { - Travel is modeled as intermediate } \\
\text { goods (derived demand for trips) }\end{array}$ & $\begin{array}{l}\text { - Value of time depends on marginal } \\
\text { (not average) wage rate } \\
\text { - Price of trip only partially depends on } \\
\text { travel time } \\
\text { - Value of time varies between } \\
\text { individuals depending on income, wage } \\
\text { rate, purpose, urgency, etc. } \\
\text { - Travel decisions are affected by value } \\
\text { of time and trip-based direct utility }\end{array}$ \\
\hline 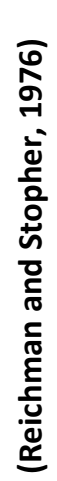 & & $\begin{array}{l}\text { - Various forms of incorporating value } \\
\text { of time in travel demand models are } \\
\text { discussed }\end{array}$ & $\begin{array}{l}\text { - It is not possible to determine if value } \\
\text { of time savings can be equivalent to } \\
\text { value of total travel time }\end{array}$ \\
\hline 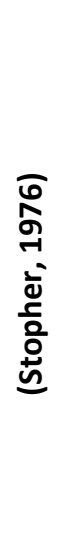 & & $\begin{array}{l}\text { - Discusses models based on } \\
\text { application of disaggregate behavioral } \\
\text { theories and concepts to travel } \\
\text { demand modeling } \\
\text { - Discusses and compares logit, and } \\
\text { probit specifications } \\
\text { - Problems with applying logit analysis } \\
\text { to multiple-choice situations are } \\
\text { reviewed }\end{array}$ & $\begin{array}{l}\text { - The value of travel time varies by trip } \\
\text { purpose } \\
\text { - Time and cost savings can be valued } \\
\text { differently depending on trip length } \\
\text { - It might not be appropriate to } \\
\text { extrapolate values of savings beyond } \\
\text { the range of observed data } \\
\text { - For small time savings, estimated } \\
\text { value of time is likely to be subject to } \\
\text { considerable random variance }\end{array}$ \\
\hline
\end{tabular}

33

Center for Urban Transportation Research | National Center for Transit Research 


\begin{tabular}{|c|c|c|c|}
\hline $\begin{array}{l}\text { 굴 } \\
\text { 苞 }\end{array}$ & $\begin{array}{l}\text { Sample size; geographic } \\
\text { scale; data used }\end{array}$ & $\begin{array}{l}\text { Estimation process; } \\
\text { relevant variables }\end{array}$ & Findings \\
\hline 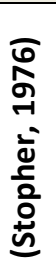 & & $\begin{array}{l}\text { - Techniques used in transportation } \\
\text { investment projects are reviewed } \\
\text { - Implications of the value of travel } \\
\text { time for cost-effectiveness analyses } \\
\text { are examined }\end{array}$ & $\begin{array}{l}\text { - Concept of travel time savings refers } \\
\text { to diversion of time for alternative use } \\
\text { - Value of time is related to individual's } \\
\text { perception of alternative use of saved } \\
\text { time }\end{array}$ \\
\hline 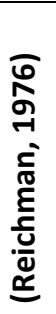 & & $\begin{array}{l}\text { - Various conceptual problems in the } \\
\text { evaluation of time are discussed } \\
\text { - Two economic analyses of the value } \\
\text { of time are compared }\end{array}$ & $\begin{array}{l}\text { - Value of travel time depends both on } \\
\text { alternative use of saved time and the } \\
\text { disutility of traveling } \\
\text { - Not all saved time can be used for } \\
\text { productive purposes }\end{array}$ \\
\hline 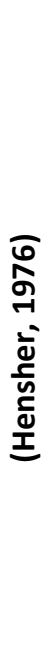 & & $\begin{array}{l}\text { - Several studies and approaches to } \\
\text { valuation of travel time are reviewed } \\
\text { - Reviewed studies estimate value of } \\
\text { time as by-product of single and } \\
\text { simultaneous travel choice and } \\
\text { demand models } \\
\text { - Analyzed travel choice models } \\
\text { emphasize predicting rather than } \\
\text { capturing the essence of the notion of } \\
\text { the value of travel time }\end{array}$ & $\begin{array}{l}\text { - Value derived from mode choice } \\
\text { studies is a composite of pure value of } \\
\text { time and comfort and convenience } \\
\text { features of different modes } \\
\text { - It is required to separate the } \\
\text { opportunity cost of time and the } \\
\text { disutility of time spent traveling } \\
\text { - Many reviewed empirical studies used } \\
\text { inadequate sample sizes to estimate } \\
\text { travel time savings } \\
\text { - Value of travel time savings is assumed } \\
\text { to be a function of income, but more } \\
\text { research is needed }\end{array}$ \\
\hline
\end{tabular}

34

Center for Urban Transportation Research | National Center for Transit Research 


\begin{tabular}{|c|c|c|c|}
\hline 方 & $\begin{array}{l}\text { Sample size; geographic } \\
\text { scale; data used }\end{array}$ & $\begin{array}{c}\text { Estimation process; } \\
\text { relevant variables }\end{array}$ & Findings \\
\hline 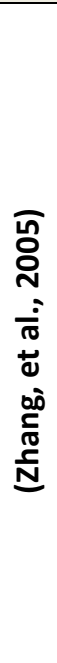 & $\begin{array}{l}\text { - Activity-travel diary data for } 257 \\
\text { households in southern Rotterdam } \\
\text { region, Netherlands }\end{array}$ & $\begin{array}{l}\text { - Model of household task allocation } \\
\text { and time use based on multi-linear } \\
\text { group utility function } \\
\text { - Utility function is maximized subject } \\
\text { to each member's time constraint } \\
\text { - In-home, out-of-home individual and } \\
\text { joint activities modeled } \\
\text { - Explanatory variables include: age of } \\
\text { oldest household member, number of } \\
\text { wage earners, number of passenger } \\
\text { cars and bikes, weekly official working } \\
\text { hours, travel time }\end{array}$ & $\begin{array}{l}\text { - Husband has the highest influence in } \\
\text { the allocation of time in nearly half of } \\
\text { the households } \\
\text { - Wife has more influence in one-fifth of } \\
\text { the households } \\
\text { - The remaining households show } \\
\text { evidence of equal relative influence } \\
\text { - Household members may use different } \\
\text { group decision strategies (bargaining, } \\
\text { turn-taking, compromising) } \\
\text { - Incorporating influence of travel time } \\
\text { significantly improves accuracy }\end{array}$ \\
\hline 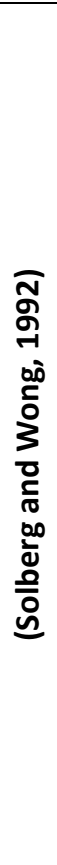 & $\begin{array}{l}\text { - Data from 1977-78 Family time } \\
\text { use survey } \\
\text { - Data covers eleven states } \\
\text { - } 628 \text { observations used for } \\
\text { estimation of time-use equations }\end{array}$ & $\begin{array}{l}\text { - A two-earner Gronau-type } \\
\text { neoclassical model of the allocation of } \\
\text { time } \\
\text { - Model consists of } 6 \text { simultaneous } \\
\text { equations; quadratic specification for } \\
\text { time-use equations } \\
\text { - Time use for each person is divided } \\
\text { into three basic activities: market } \\
\text { work, home production, and pure } \\
\text { leisure, plus work related travel } \\
\text { - Travel time is treated as } \\
\text { predetermined } \\
\text { - Transportation costs are directly } \\
\text { proportional to travel time } \\
\text { - The model controls for the effects of } \\
\text { income taxation }\end{array}$ & $\begin{array}{l}\text { - Travel time is a significant explanatory } \\
\text { variable in time use decisions or both } \\
\text { husband and wife } \\
\text { - Omission of travel time is likely to } \\
\text { cause omitted variable bias }\end{array}$ \\
\hline
\end{tabular}




\begin{tabular}{|c|c|c|c|}
\hline$\frac{7}{0}$ & $\begin{array}{c}\text { Sample size; geographic } \\
\text { scale; data used }\end{array}$ & $\begin{array}{c}\text { Estimation process; } \\
\text { relevant variables }\end{array}$ & Findings \\
\hline 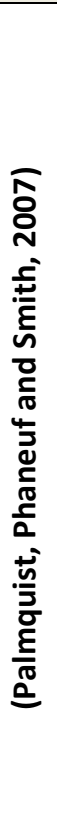 & $\begin{array}{l}\text { - Data collected through mail } \\
\text { survey between May and } \\
\text { September } 2003 \\
\text { - } 9000 \text { households in Wake } \\
\text { County, NC surveyed } \\
\text { - } 1,719 \text { usable responses were } \\
\text { received } \\
\text { - Both revealed and stated } \\
\text { preference data }\end{array}$ & $\begin{array}{l}\text { - Employs a new model for time } \\
\text { valuation that uses time commitments } \\
\text { to distinguish consumers' choice } \\
\text { margins and different value of time } \\
\text { they imply } \\
\text { - Decisions are assumed to take place } \\
\text { over different time horizons, made as } \\
\text { part of long-run choices } \\
\text { - Quadratic and log form of the } \\
\text { household production function were } \\
\text { examined }\end{array}$ & $\begin{array}{l}\text { - Many leisure time activities take place } \\
\text { in relatively small blocks of time and the } \\
\text { value of time may differ depending on } \\
\text { the size of the block } \\
\text { - Marginal value of time can be } \\
\text { increasing when longer time blocks are } \\
\text { used } \\
\text { - Frequency and timing of non-market } \\
\text { activities, short-run time constraints, } \\
\text { and production technology affect } \\
\text { shadow value of time } \\
\text { - Shadow value of time does not need } \\
\text { to be equal to the wage rate } \\
\text { - Mean predicted VOT estimated at } \\
\$ 26.64 \text { and median is } \$ 19.61 \text { (in } 2003 \\
\text { dollars) }\end{array}$ \\
\hline 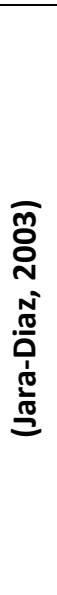 & & $\begin{array}{l}\text { - Static consumer behavior model is } \\
\text { used } \\
\text { - Two types of function were defined } \\
\text { to account for all implicit and explicit } \\
\text { technological feasibility constraints } \\
\text { - Four types of relationships between } \\
\text { goods and activities (minimum and } \\
\text { maximum time-dependent } \\
\text { consumption levels, and minimum and } \\
\text { maximum goods-dependent time } \\
\text { allocation) were modeled and } \\
\text { explored }\end{array}$ & $\begin{array}{l}\text { - Findings support DeSepra's (1971) } \\
\text { findings regarding minimum time } \\
\text { requirements for consumption of goods } \\
\text { - The value of leisure activities differs } \\
\text { across activities due to variation in } \\
\text { goods consumption }\end{array}$ \\
\hline
\end{tabular}




\begin{tabular}{|c|c|c|c|}
\hline $\begin{array}{l}\frac{2}{0} \\
\dot{n} \\
n\end{array}$ & $\begin{array}{l}\text { Sample size; geographic } \\
\text { scale; data used }\end{array}$ & $\begin{array}{l}\text { Estimation process; } \\
\text { relevant variables }\end{array}$ & Findings \\
\hline 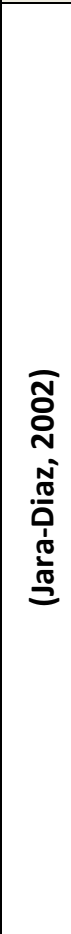 & & $\begin{array}{l}\text { - Expanded goods/leisure trade-off } \\
\text { model } \\
\text { - General conditional indirect utility } \\
\text { function is maximized within a } \\
\text { framework of discrete travel choices } \\
\text { - Work and travel time are included in } \\
\text { the analysis as direct sources of utility } \\
\text { - The cases of endogenous and } \\
\text { exogenous income are analyzed } \\
\text { - Analysis is focused on the role of } \\
\text { marginal utilities for the interpretation } \\
\text { of the subjective value of travel time }\end{array}$ & $\begin{array}{l}\text { - Relationship between goods } \\
\text { consumption and consumption time } \\
\text { (including minimum time required) is } \\
\text { extremely important } \\
\text { - When income is endogenous, } \\
\text { subjective value of travel time has three } \\
\text { components: wage rate, direct } \\
\text { subjective value of work, subjective } \\
\text { value of travel time } \\
\text { - With exogenous income, subjective } \\
\text { value of time has two components } \\
\text { (value of time itself and subjective value } \\
\text { of work) if individual works more than } \\
\text { required } \\
\text { - When income is exogenous and } \\
\text { individual works strictly according to } \\
\text { contract, there is a third term that } \\
\text { accounts for the difference between } \\
\text { subjective value of work and leisure }\end{array}$ \\
\hline
\end{tabular}

37

Center for Urban Transportation Research | National Center for Transit Research 


\begin{tabular}{|c|c|c|c|}
\hline 굴 & $\begin{array}{c}\text { Sample size; geographic } \\
\text { scale; data used }\end{array}$ & $\begin{array}{c}\text { Estimation process; } \\
\text { relevant variables }\end{array}$ & Findings \\
\hline 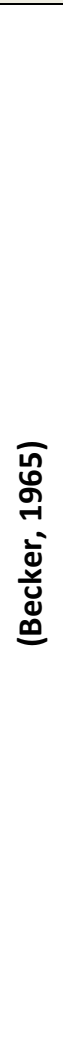 & & $\begin{array}{l}\text { - Model of the allocation of time } \\
\text { between different activities } \\
\text { - Households are both producers and } \\
\text { consumers } \\
\text { - Commodities are produced in } \\
\text { quantities determined by maximizing } \\
\text { a utility function of the commodity set } \\
\text { subject to prices and resources } \\
\text { constraint } \\
\text { - Households produce commodities by } \\
\text { combining inputs of goods and time } \\
\text { according to cost-minimizing rules of } \\
\text { the traditional theory of the firm } \\
\text { - Resources are measured by full } \\
\text { income (money income plus foregone } \\
\text { earnings due to the consumption of } \\
\text { goods) } \\
\text { - Commuting time yields no (dis)utility } \\
\text { (commuting time does not enter the } \\
\text { utility function) }\end{array}$ & $\begin{array}{l}\text { - Substitution effect of a rise in earnings } \\
\text { is more important than commonly } \\
\text { believed } \\
\text { - The source of income may have a } \\
\text { significant effect on consumption } \\
\text { patterns } \\
\text { - The substitution effects of the growth } \\
\text { in productivity of working and } \\
\text { consumption time offset each other; } \\
\text { hours worked declined over time (in the } \\
\text { US) primarily because time-intensive } \\
\text { commodities have been luxuries } \\
\text { - The increase in earnings, total income } \\
\text { held constant, decreases the demand } \\
\text { for time-intensive commodities and } \\
\text { input combinations } \\
\text { - Foregone earnings are quantitatively } \\
\text { important and should be accounted for } \\
\text { in the full income }\end{array}$ \\
\hline 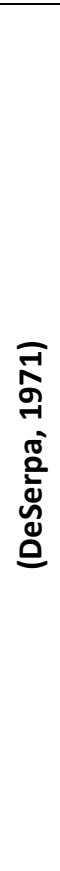 & & $\begin{array}{l}\text { - The analysis follows neoclassical } \\
\text { consumer theory approach } \\
\text { Main assumptions and features of the } \\
\text { approach: } \\
\text { - Utility is a function not only of } \\
\text { commodities but also of the time } \\
\text { allocated to them } \\
\text { - The individual's decision is subject to } \\
\text { money and time constraints } \\
\text { - Consumption of goods requires that } \\
\text { some minimum amount of time is } \\
\text { allocated to it but individual may } \\
\text { spend more time in that activity if he } \\
\text { so desires } \\
\text { - Commuting time can cause } \\
\text { (dis)utility }\end{array}$ & $\begin{array}{l}\text { - The amount of time spent in any } \\
\text { activity is partly a matter of choice and } \\
\text { partly a matter of necessity } \\
\text { - When it's the matter of necessity, an } \\
\text { additional constraint becomes binding } \\
\text { upon consumer's preferences } \\
\text { - When it is solely a matter of choice the } \\
\text { constraint is not effective and "time } \\
\text { prices" have no effect on the } \\
\text { consumer's decision } \\
\text { - The difference between scarcity value } \\
\text { and commodity value of time is defined } \\
\text { as "value of time saved" }\end{array}$ \\
\hline
\end{tabular}




\begin{tabular}{|c|c|c|c|}
\hline 훌 & $\begin{array}{c}\text { Sample size; geographic } \\
\text { scale; data used }\end{array}$ & $\begin{array}{c}\text { Estimation process; } \\
\text { relevant variables }\end{array}$ & Findings \\
\hline 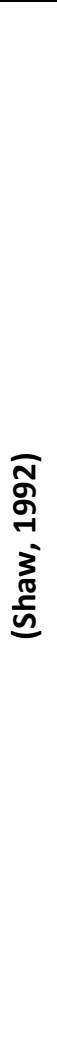 & & $\begin{array}{l}\text { - Household production model where } \\
\text { individual uses time and goods to } \\
\text { produce "commodities" } \\
\text { - Utility is maximized subject to } \\
\text { budget constraint and the constraint } \\
\text { of time available } \\
\text { - Time is an input not a commodity } \\
\text { - The opportunity cost of time in one } \\
\text { activity is the lost utility from } \\
\text { producing the next best alternative } \\
\text { activity, whatever that activity might } \\
\text { be }\end{array}$ & $\begin{array}{l}\text { - Marginal rate of substitution between } \\
\text { labor and leisure equal to the wage rate } \\
\text { refers to opportunity cost of time rather } \\
\text { than value of time } \\
\text { - Low wage may imply low opportunity } \\
\text { cost of time but not necessarily low } \\
\text { value of time } \\
\text { - The value and opportunity cost of time } \\
\text { is significantly influenced by how the } \\
\text { utility function is modeled and the } \\
\text { nature of activity } \\
\text { - Multiple constraints or non-linear } \\
\text { constraints can cause the individuals at } \\
\text { corner solutions (e.g., when an } \\
\text { individual has little discretionary power } \\
\text { over work time) to have high, though } \\
\text { not directly observable, opportunity } \\
\text { cost of time } \\
\text { - The opportunity cost of time may vary } \\
\text { from some fraction of the wage rate to } \\
\text { two-three times the wage rate }\end{array}$ \\
\hline 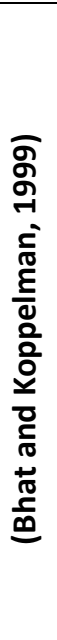 & & $\begin{array}{l}\text { - The paper reviews theoretical and } \\
\text { empirical research in the areas of } \\
\text { activity time allocation and activity } \\
\text { episode analysis } \\
\text { - The comparison is made between } \\
\text { trip-based approach, where time is } \\
\text { treated simply as a "cost" of making a } \\
\text { trip, and activity-based approach, } \\
\text { which treats time as a continuous } \\
\text { entity within which individuals make } \\
\text { activity/travel participation decisions }\end{array}$ & $\begin{array}{l}\text { - Activity-based travel paradigm is being } \\
\text { increasingly accepted as the basis for } \\
\text { travel demand analysis } \\
\text { - The methods that recognize } \\
\text { continuous nature of time, such as, } \\
\text { hazard-based duration analysis, limited- } \\
\text { dependent variable models, and } \\
\text { computational process models, become } \\
\text { more accepted in travel demand } \\
\text { modeling } \\
\text { - Traditional discrete choice models are } \\
\text { unable to accommodate the continuous } \\
\text { nature of time }\end{array}$ \\
\hline
\end{tabular}

39

Center for Urban Transportation Research | National Center for Transit Research 


\begin{tabular}{|c|c|c|c|}
\hline 훌 & $\begin{array}{c}\text { Sample size; geographic } \\
\text { scale; data used }\end{array}$ & $\begin{array}{c}\text { Estimation process; } \\
\text { relevant variables }\end{array}$ & Findings \\
\hline 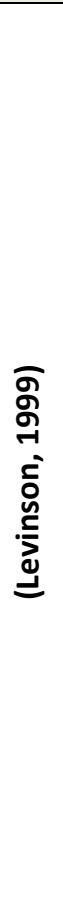 & $\begin{array}{l}\text { - Data from 1990/91 National } \\
\text { Personal Transportation Survey } \\
\text { (NPTS) conducted by the Research } \\
\text { Triangle Institute } \\
\text { - Survey covers data on household } \\
\text { demographics, income, vehicle } \\
\text { availability, and all trips made on } \\
\text { the survey day } \\
\text { - Data covers } 22,000 \text { households, } \\
\text { over } 47,000 \text { people, and almost } \\
150,000 \text { trips }\end{array}$ & $\begin{array}{l}\text { - The paper examines how } \\
\text { demographic, socioeconomic, } \\
\text { seasonal and scheduling factors affect } \\
\text { the allocation of time to various } \\
\text { activities } \\
\text { - The analysis examines how much can } \\
\text { activity duration and frequency } \\
\text { explain travel duration } \\
\text { - The research explicitly considered } \\
\text { rarely addressed spatial factors, } \\
\text { quantified their statistical significance, } \\
\text { and measured their importance for } \\
\text { long-term time allocation shifts }\end{array}$ & $\begin{array}{l}\text { - Activity duration has positive and } \\
\text { significant effect on travel duration } \\
\text { - Time at home and time at shop are } \\
\text { positively associated, while no } \\
\text { correlation was found between other } \\
\text { activities } \\
\text { - Time per activity shows only small } \\
\text { variations explainable by economic, } \\
\text { demographic, spatial, or temporal } \\
\text { factors } \\
\text { - Travel and work are positively } \\
\text { associated with income } \\
\text { - The rise in travel over past few } \\
\text { decades can be largely attributed to the } \\
\text { discretionary time loss due to changes } \\
\text { in female labor force participation } \\
\text { rather than the rise in low-density living } \\
\text { or per-capita income }\end{array}$ \\
\hline
\end{tabular}




\begin{tabular}{|c|c|c|c|}
\hline $\begin{array}{l}\text { 후 } \\
\text { ثे } \\
\text { n }\end{array}$ & $\begin{array}{c}\text { Sample size; geographic } \\
\text { scale; data used }\end{array}$ & $\begin{array}{l}\text { Estimation process; } \\
\text { relevant variables }\end{array}$ & Findings \\
\hline 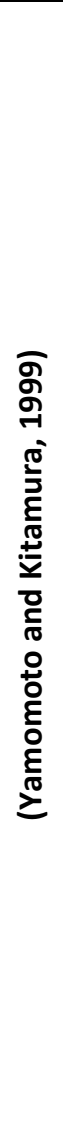 & $\begin{array}{l}\text { - Data from time-use diary survey } \\
\text { conducted in Netherlands in } 1985 \\
\text { - Data sample included 2,964 } \\
\text { respondents of at least } 18 \text { years } \\
\text { old } \\
\text { - Respondents reported their } \\
\text { primary activities for } 96 \text { 15-minute } \\
\text { periods in each day for seven days }\end{array}$ & $\begin{array}{l}\text { - Time allocation is formulated as a } \\
\text { doubly-censored Tobit model } \\
\text { - Non-parametric technique is } \\
\text { involved in describing errors } \\
\text { distribution } \\
\text { - Explanatory variables of the model } \\
\text { include: age, presence of children, } \\
\text { gender, household size, household } \\
\text { income, work hours, commute time, } \\
\text { flexibility of work hours, number of } \\
\text { vehicles, etc. } \\
\text { - The model examines individual's } \\
\text { allocation of time to in-home and out- } \\
\text { of-home discretionary activities on } \\
\text { working days and non-working days } \\
\text { - Both random and systematic inter- } \\
\text { personal (across different individuals) } \\
\text { and intra-personal (from day to day } \\
\text { for one individual) variability in } \\
\text { behavior is analyzed }\end{array}$ & $\begin{array}{l}\text { - About } 70 \% \text { of sample workers tend to } \\
\text { allocate relatively more time to out-of- } \\
\text { home activities on working days and } \\
\text { relatively more time to in-home } \\
\text { activities on non-working days } \\
\text { - 30\% of workers have unaccounted } \\
\text { orientation toward in-home activities } \\
\text { on both working days and non-working } \\
\text { days } \\
\text { - Age and presence of children } \\
\text { significantly affect time allocation on } \\
\text { both working days and non-working } \\
\text { days } \\
\text { - Household size affects behavior only } \\
\text { on working days } \\
\text { - Income is not associated with the split } \\
\text { in time between in-home and out-of- } \\
\text { home activities } \\
\text { - Intra-personal systematic variations } \\
\text { are larger for those in larger households } \\
\text { and for households with higher car } \\
\text { availability }\end{array}$ \\
\hline 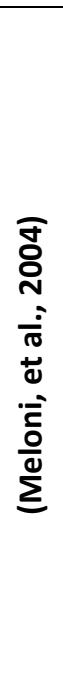 & $\begin{array}{l}\text { - The data from the activity based } \\
\text { travel survey conducted in the } \\
\text { urban area of Cagliari, Italy in } \\
1998 \\
\text { - Survey covered households with } \\
\text { no children of pre-school or school } \\
\text { age in which at least one individual } \\
\text { had made trip towards the central } \\
\text { business district of Cagliari } \\
\text { - The data sample consists of } 235 \\
\text { individuals }\end{array}$ & $\begin{array}{l}\text { - A Nested-Tobit model is used } \\
\text { (discrete-continuous model with } \\
\text { limited dependent variable) } \\
\text { - The hierarchical sequence of two } \\
\text { equations describes how the } \\
\text { individuals choose to allocate their } \\
\text { discretionary time between in- and } \\
\text { out-of-home activities (first equation) } \\
\text { and between trips and activities } \\
\text { (second equation) } \\
\text { - The controlled socio-economic } \\
\text { variables include: age, number of } \\
\text { persons in household, number of cars, } \\
\text { working in paid work, etc. }\end{array}$ & $\begin{array}{l}\text { - Socio-economic variables are } \\
\text { insignificant in explaining the trade-off } \\
\text { between in-home and out-of-home } \\
\text { discretionary activities } \\
\text { - Socio-economic attributes have more } \\
\text { influence on the choice of how much } \\
\text { time to dedicate for trips, once the } \\
\text { decision to engage in out-of-home } \\
\text { activities has been made } \\
\text { - The number of trips and the time } \\
\text { allocated to mandatory trips are the } \\
\text { two activity variables that most } \\
\text { influence the substitution the activity } \\
\text { with trip time }\end{array}$ \\
\hline
\end{tabular}




\begin{tabular}{|c|c|c|c|}
\hline $\begin{array}{l}\frac{\lambda}{0} \\
\text { Dे } \\
\text { n }\end{array}$ & $\begin{array}{c}\text { Sample size; geographic } \\
\text { scale; data used }\end{array}$ & $\begin{array}{l}\text { Estimation process; } \\
\text { relevant variables }\end{array}$ & Findings \\
\hline 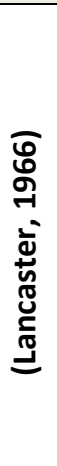 & & $\begin{array}{l}\text { - The new model of consumer } \\
\text { preferences is suggested that } \\
\text { emphasizes activity analysis } \\
\text { - Consumption is the activity where } \\
\text { goods are treated as inputs } \\
\text { - Consumers rank their preferences } \\
\text { based on the collection of } \\
\text { characteristics that the goods possess, } \\
\text { not on goods themselves }\end{array}$ & $\begin{array}{l}\text { - The developed model demonstrates a } \\
\text { greater predictive and explanatory } \\
\text { power than conventional models of } \\
\text { consumer behavior } \\
\text { - Labor-leisure choice may have market } \\
\text { occupational pattern rather than just } \\
\text { being based on individual preferences }\end{array}$ \\
\hline 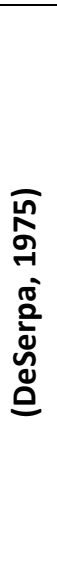 & & $\begin{array}{l}\text { - The paper questions the significance } \\
\text { of the demand theorems related to } \\
\text { time allocation theory }\end{array}$ & $\begin{array}{l}\text { - Traditional demand theorems are only } \\
\text { valid in the case of two activities } \\
\text { produced by means of fixed coefficient } \\
\text { production function under the } \\
\text { assumption that the price of time is } \\
\text { equal to the individual's wage rate } \\
\text { - In time allocation theory substitution } \\
\text { effects are associated with wage } \\
\text { changes which are highly correlated } \\
\text { with income changes. Therefore, the } \\
\text { income effect should be the dominant } \\
\text { factor in time allocation }\end{array}$ \\
\hline 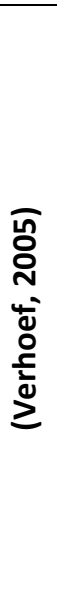 & & $\begin{array}{l}\text { - A spatial general equilibrium model } \\
\text { is used with endogenous labor supply } \\
\text { and residential density } \\
\text { - Congestion pricing schemes that are } \\
\text { second-best "by design" (such as, } \\
\text { cordon charging, flat kilometer charge, } \\
\text { etc.) are analyzed } \\
\text { - Two functional specifications are } \\
\text { explored: Cobb-Douglass utility } \\
\text { function and Constant Elasticity of } \\
\text { Substitution (CES) utility function }\end{array}$ & $\begin{array}{l}\text { - Analysis concludes the relative } \\
\text { effectiveness of cordon pricing in the } \\
\text { monocentric city (reported by Mun et } \\
\text { al.) even when accounting for } \\
\text { residential land markets, endogenous } \\
\text { labor supply and general spatial } \\
\text { equilibrium conditions } \\
\text { - Relative welfare loss from second-best } \\
\text { pricing, compared to first-best pricing, } \\
\text { is surprisingly small } \\
\text { - The results are valid for both Cobb- } \\
\text { Douglass and CES utility function }\end{array}$ \\
\hline
\end{tabular}

42

Center for Urban Transportation Research | National Center for Transit Research 


\begin{tabular}{|c|c|c|c|}
\hline$\frac{\lambda}{2}$ & $\begin{array}{l}\text { Sample size; geographic } \\
\text { scale; data used }\end{array}$ & $\begin{array}{l}\text { Estimation process; } \\
\text { relevant variables }\end{array}$ & Findings \\
\hline 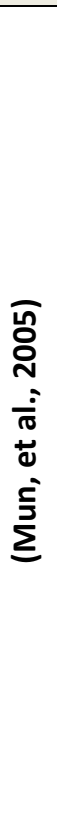 & $\begin{array}{l}\text { - Trip survey data for Osaka } \\
\text { prefecture, Japan }\end{array}$ & $\begin{array}{l}\text { - Urban spatial model of traffic } \\
\text { congestion in a non-monocentric city } \\
\text { is used } \\
\text { - The efficiency of resource allocation } \\
\text { is evaluated for three alternative } \\
\text { pricing schemes: no-toll equilibrium, } \\
\text { first-best optimum, and optimal } \\
\text { cordon pricing } \\
\text { - Optimal cordon pricing is defined as } \\
\text { a combination of cordon location and } \\
\text { toll level that maximizes the social } \\
\text { surplus in a city }\end{array}$ & $\begin{array}{l}\text { - Effectiveness of cordon pricing } \\
\text { depends on various factors, including a } \\
\text { city's spatial structure and other } \\
\text { parameters } \\
\text { - Welfare improvement from } \\
\text { introducing cordon pricing is relatively } \\
\text { larger when: } \\
\text { * the urban spatial structure is close to } \\
\text { monocentric } \\
* \text { the density gradient is steeper } \\
\text { * trip demand is less elastic } \\
* \text { road capacity is larger } \\
\text { - Cordon pricing is likely to be more } \\
\text { effective in small cities }\end{array}$ \\
\hline 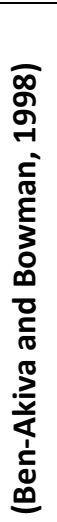 & $\begin{array}{l}\text { - } 1991 \text { data from } 24 \text {-hour } \\
\text { household travel diary survey } \\
\text { - The survey covers 1,259 } \\
\text { households and 5,232 persons in } \\
\text { Boston metropolitan area }\end{array}$ & $\begin{array}{l}\text { - Nested-logit specification of the } \\
\text { model is used } \\
\text { - A daily schedule consists of tours, } \\
\text { characterized by destinations, times of } \\
\text { day and travel modes } \\
\text { - Performance and predictive power of } \\
\text { activity-based model and residential- } \\
\text { choice model are compared }\end{array}$ & $\begin{array}{l}\text { - Residential choice model does not fit } \\
\text { the data as good as activity-based } \\
\text { model but its predictions capture } \\
\text { additional aspects of accessibility } \\
\text { - Daily activity pattern decisions should } \\
\text { be modeled as longer-tern decisions } \\
\text { - Activity-based model can better } \\
\text { explain the travel choices of the } \\
\text { individuals }\end{array}$ \\
\hline
\end{tabular}




\begin{tabular}{|c|c|c|c|}
\hline$\frac{7}{0}$ & $\begin{array}{c}\text { Sample size; geographic } \\
\text { scale; data used }\end{array}$ & $\begin{array}{c}\text { Estimation process; } \\
\text { relevant variables }\end{array}$ & Findings \\
\hline 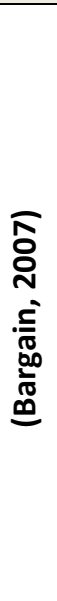 & $\begin{array}{l}\text { - French household budget survey } \\
\text { 1994, with monetary variables } \\
\text { grossed up to } 1998 \\
\text { - Data for 3,548 married or } \\
\text { cohabitating couples where adult } \\
\text { members are } 25-64 \text { years old, with } \\
\text { not more than } 3 \text { children, and } \\
\text { where wife is available for the } \\
\text { labor market }\end{array}$ & $\begin{array}{l}\text { - Three discrete-choice labor supply } \\
\text { models are reviewed and compared: } \\
\text { structural model, unconstrained } \\
\text { model and general model with price- } \\
\text { and income- policy analysis } \\
\text { - Multinomial logit models are used } \\
\text { and tested for unobserved } \\
\text { heterogeneity } \\
\text { - Households' responses to various } \\
\text { policies are studied by relaxing some } \\
\text { of the assumptions and restrictions of } \\
\text { the standard structural model }\end{array}$ & $\begin{array}{l}\text { - All three reviewed models yield } \\
\text { significantly different response to tax } \\
\text { reform } \\
\text { - The assumption of static optimization } \\
\text { by households is strongly rejected when } \\
\text { tested against general model with price- } \\
\text { and income-dependent preferences } \\
\text { - Restrictions from both structural and } \\
\text { standard models cause discrepancies in } \\
\text { predicted responses to a tax reform }\end{array}$ \\
\hline 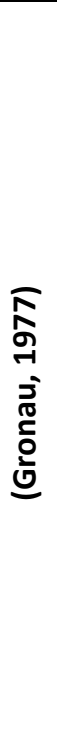 & $\begin{array}{l}\text { - } 1972 \text { panel data from the } \\
\text { Michigan study of income } \\
\text { dynamics } \\
\text { - The sample included 1,281 white } \\
\text { married women, of whom } 660 \\
\text { were employed and } 621 \text { did not } \\
\text { work }\end{array}$ & $\begin{array}{l}\text { - Allocation of time between market } \\
\text { work, work at home, and leisure is } \\
\text { studied } \\
\text { - Assumptions of the model: } \\
\text { 1. home-produced goods are perfect } \\
\text { substitutes for market goods } \\
\text { 2. home production is subject to } \\
\text { diminishing marginal productivity } \\
\text { - Explanatory variables include: wife's } \\
\text { age, education, labor force } \\
\text { experience, husband's education and } \\
\text { wage, number of children, family's } \\
\text { unearned income, number of children, } \\
\text { number of rooms in the house }\end{array}$ & $\begin{array}{l}\text { - When the wife is not employed her } \\
\text { work at home is negatively affected by } \\
\text { her unearned income and her } \\
\text { husband's wage rate } \\
\text { - When woman is employed the major } \\
\text { determinant of her allocation of time is } \\
\text { her wage rate } \\
\text { - Work at home is negatively associated } \\
\text { with wife's education and positively } \\
\text { associated with the size of the house } \\
\text { and presence of small children } \\
\text { - The husband's wage rate has } \\
\text { significant positive effect on leisure, but } \\
\text { no effect on work at home }\end{array}$ \\
\hline
\end{tabular}




\begin{tabular}{|c|c|c|c|}
\hline$\frac{7}{0}$ & $\begin{array}{c}\text { Sample size; geographic } \\
\text { scale; data used }\end{array}$ & $\begin{array}{l}\text { Estimation process; } \\
\text { relevant variables }\end{array}$ & Findings \\
\hline 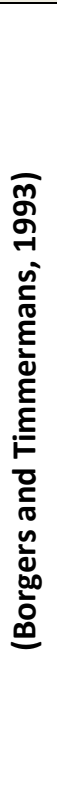 & $\begin{array}{l}\text { - Data for } 95 \text { dual income } \\
\text { households in Netherlands, } 1991\end{array}$ & $\begin{array}{l}\text { - The analysis examines how } \\
\text { residential location choice is related to } \\
\text { the existence of public transportation } \\
\text { facilities and distance to workplace } \\
\text { - The following parameter are } \\
\text { included in the analysis: } \\
\text { a) the residence itself (dwelling type, } \\
\text { costs, etc.) } \\
\text { b) the transportation facilities in the } \\
\text { neighborhood } \\
\text { c) travel time from residence location } \\
\text { to workplace } \\
\text { - Residential location choice is made } \\
\text { jointly (multi-person decision making) }\end{array}$ & $\begin{array}{l}\text { - Residential location preference is } \\
\text { primarily dependent on the } \\
\text { characteristics of the dwelling and its } \\
\text { environment, and to a lesser extent on } \\
\text { the travel time to workplace } \\
\text { - The characteristics of transportation } \\
\text { facilities are not very important in the } \\
\text { choice of residential location } \\
\text { - Housing policy and urban planning } \\
\text { programs can be more effective than } \\
\text { transportation policy in influencing } \\
\text { residential choice behavior and mobility }\end{array}$ \\
\hline 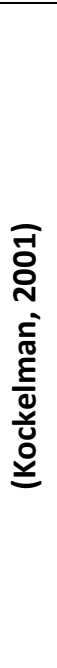 & $\begin{array}{l}\text { - } 1990 \text { San Francisco Bay Area } \\
\text { Travel Survey describing trip- } \\
\text { making and out-of-home activity } \\
\text { participation for over 10,000 } \\
\text { households } \\
\text { - Household is viewed as a unit; } \\
\text { intra-household decisions and } \\
\text { trade-offs are not considered }\end{array}$ & $\begin{array}{l}\text { - Simultaneous-equations model of } \\
\text { participation in discretionary out-of- } \\
\text { home activities } \\
\text { - Household's utility is maximized } \\
\text { subject to time and money constraints } \\
\text { - Multivariate negative binomial } \\
\text { stochastic specification is used }\end{array}$ & $\begin{array}{l}\text { - The hypothesis of inelastic travel } \\
\text { demand with respect to travel time } \\
\text { costs is rejected } \\
\text { - People substitute distant activities for } \\
\text { nearer activities when travel time to } \\
\text { distant activities increases } \\
\text { - When income increases travelers tend } \\
\text { to purchase higher speeds and travel } \\
\text { longer distances, instead of generating } \\
\text { more trips } \\
\text { - When travel speeds increase travelers } \\
\text { prefer to trade-off saved time for longer } \\
\text { trips rather than for more trips }\end{array}$ \\
\hline
\end{tabular}




\begin{tabular}{|c|c|c|c|}
\hline$\frac{7}{0}$ & $\begin{array}{c}\text { Sample size; geographic } \\
\text { scale; data used }\end{array}$ & $\begin{array}{l}\text { Estimation process; } \\
\text { relevant variables }\end{array}$ & Findings \\
\hline 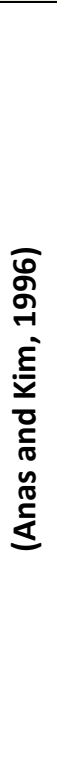 & $\begin{array}{l}\text { Numerical simulation of a general } \\
\text { computable equilibrium model. }\end{array}$ & $\begin{array}{l}\text { - A computable general equilibrium } \\
\text { model of urban land use } \\
\text { - Major assumptions: } \\
\text { 1. Land is allocated to houses, } \\
\text { production and roads } \\
\text { 2. Traffic congestion and employment } \\
\text { locations are determined } \\
\text { endogenously } \\
\text { 3. No inter-industry trade } \\
\text { 4. No economies of scale in shopping }\end{array}$ & $\begin{array}{l}\text { - Without scale economies in shopping, } \\
\text { production is dispersed with rent, wage, } \\
\text { commodity price, and net density } \\
\text { gradients, all peaking at the center of } \\
\text { the space } \\
\text { - When scale economies in shopping are } \\
\text { strong relative to the cost of traffic } \\
\text { congestion, dispersion becomes } \\
\text { unstable } \\
\text { - With stronger agglomeration, there } \\
\text { are fewer and bigger centers (utility is } \\
\text { higher with fewer centers) } \\
\text { - With higher congestion the number of } \\
\text { centers increases (utility is higher with } \\
\text { more centers) }\end{array}$ \\
\hline 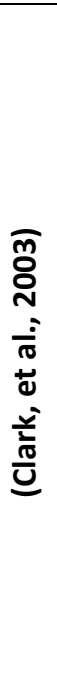 & $\begin{array}{l}\text { - Longitudinal sample of } \\
\text { approximately } 2,000 \text { households } \\
\text { within the Seattle labor market, } \\
\text { collected by Puget Sound Regional } \\
\text { Council over series of years: } 1989- \\
\text { 1990, 1992-1994 and 1996-1997 } \\
\text { - Data reports residential location, } \\
\text { workplace location, and the } \\
\text { distance and time of the journey } \\
\text { to work for each employed } \\
\text { household member }\end{array}$ & $\begin{array}{l}\text { - Probability model of work-place } \\
\text { attraction } \\
\text { - Multi-node, rather than mono- } \\
\text { centric, structure of the city is used in } \\
\text { the analysis } \\
\text { - A model estimates the response to } \\
\text { changes in commuting distance for } \\
\text { both one- and two-worker households }\end{array}$ & $\begin{array}{l}\text { - Both one- and two-worker households } \\
\text { with greater separation between } \\
\text { workplace and residence favor } \\
\text { decreases in distance and commute } \\
\text { time } \\
\text { - Women commute shorter distances } \\
\text { and are more likely than men to } \\
\text { minimize commuting after a move to a } \\
\text { different residential location } \\
\text { - Commute distance does matter for } \\
\text { both one- and two-worker households, } \\
\text { and households are well aware of the } \\
\text { trade-offs between distance to work } \\
\text { and residential location }\end{array}$ \\
\hline
\end{tabular}




\begin{tabular}{|c|c|c|c|}
\hline $\begin{array}{l}\frac{\lambda}{\partial} \\
\text { in }\end{array}$ & $\begin{array}{c}\text { Sample size; geographic } \\
\text { scale; data used }\end{array}$ & $\begin{array}{l}\text { Estimation process; } \\
\text { relevant variables }\end{array}$ & Findings \\
\hline 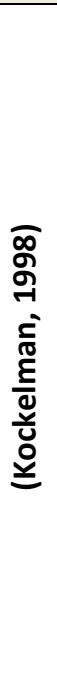 & $\begin{array}{l}\text { - } 1990 \text { San Francisco Bay Area } \\
\text { Travel Survey covering trip- } \\
\text { making of over 10,000 households } \\
\text { for periods of one, three, or five } \\
\text { workdays } \\
\text { - Household activity participation } \\
\text { is inferred from trip purpose and } \\
\text { the start/end times of consecutive } \\
\text { trips }\end{array}$ & $\begin{array}{l}\text { - Simultaneous equations model } \\
\text { - Demand equations are derived from } \\
\text { flexible functional forms of the } \\
\text { indirect utility function through } \\
\text { parallels to Roy's Identity } \\
\text { - Equations are estimated as a set of } \\
\text { negative binomial regressions, } \\
\text { produced from mixing independent } \\
\text { Poissons with stochastic gamma terms } \\
\text { accounting for unexplained } \\
\text { heterogeneity in behavior }\end{array}$ & $\begin{array}{l}\text { - Income has little effect on manifest } \\
\text { demand for discretionary activities } \\
\text { (after accounting for travel time and } \\
\text { household's time budget) } \\
\text { - Available time exerts a strong positive } \\
\text { effect on all demands } \\
\text { - Cross-travel-time elasticities are } \\
\text { negative due to strong effects of travel- } \\
\text { time changes } \\
\text { - Total travel time expenditures to } \\
\text { access discretionary activities fall with } \\
\text { increasing travel times and household's } \\
\text { time budget, not just its income }\end{array}$ \\
\hline 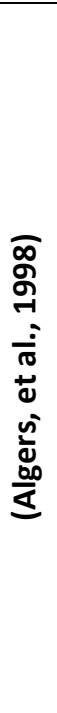 & $\begin{array}{l}\text { - } 1994 \text { Swedish Value of Time } \\
\text { study, based on a telephone } \\
\text { survey (stated preference data) } \\
\text { - The sample size contained } 850 \\
\text { car interviews, including both } \\
\text { private and business trips }\end{array}$ & $\begin{array}{l}\text { - Mixed logit model specification } \\
\text { (random parameters logit) that allows } \\
\text { parameters to vary in population } \\
\text { when estimating the value of time for } \\
\text { long-distance car travel } \\
\text { - Distribution parameters of the model } \\
\text { coefficients are estimated and } \\
\text { investigated } \\
\text { - Normal and log-normal specification } \\
\text { of parameters was analyzed }\end{array}$ & $\begin{array}{l}\text { - Value of time is significantly lower } \\
\text { when coefficients are assumed to be } \\
\text { normally distributed compared to the } \\
\text { traditional case when coefficients are } \\
\text { treated as fixed } \\
\text { - With normally distributed parameters, } \\
\text { median value of time was estimated at } \\
57 \text { Swedish Krona (SEK) per hour (\$9.52) } \\
\text { - When parameters were treated as } \\
\text { fixed, value of time was estimated at } 89 \\
\text { SEK (\$14.87) per hour } \\
\text { - The model fits the data better when } \\
\text { parameters are allowed to vary in the } \\
\text { population }\end{array}$ \\
\hline
\end{tabular}




\begin{tabular}{|c|c|c|c|}
\hline 훌 & $\begin{array}{c}\text { Sample size; geographic } \\
\text { scale; data used }\end{array}$ & $\begin{array}{l}\text { Estimation process; } \\
\text { relevant variables }\end{array}$ & Findings \\
\hline 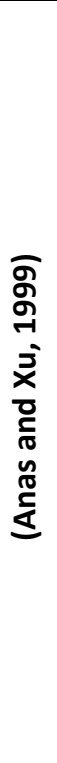 & $\begin{array}{l}\text { Numerical simulation of a general } \\
\text { computable equilibrium model }\end{array}$ & $\begin{array}{l}\text { - A general equilibrium model of } \\
\text { urban land use (similar to that of Anas } \\
\text { and Kim) } \\
\text { - The locations of firms and consumers } \\
\text { are interdependent and are } \\
\text { determined as a result of a trade-off } \\
\text { between housing and transportation } \\
\text { costs } \\
\text { - Traffic congestion is determined } \\
\text { endogenously as a function of land } \\
\text { use density } \\
\text { - Consumers value location variety for } \\
\text { shopping, but the number of trips to } \\
\text { each retail location is constrained by } \\
\text { the full cost of the trip }\end{array}$ & $\begin{array}{l}\text { - The centralizing effect of congestion } \\
\text { tolls on residents dominates the } \\
\text { decentralizing effect on firms, causing } \\
\text { the city to have more centralized job } \\
\text { and population densities } \\
\text { - The efficiency gain from levying } \\
\text { congestion tolls on work and shopping } \\
\text { travel is estimated at } 3.0 \% \text { of average } \\
\text { income } \\
\text { - About } 80 \% \text { of efficiency gains come } \\
\text { from road planning and } 20 \% \text { - from tolls }\end{array}$ \\
\hline 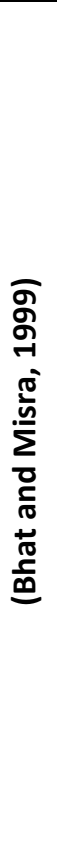 & $\begin{array}{l}\text { - } 1985 \text { time-use survey including } \\
\text { household and personal socio- } \\
\text { demographic data for } 1,547 \\
\text { individuals (heads of households) } \\
\text { in Netherlands }\end{array}$ & $\begin{array}{l}\text { - Utility function is formulated in log } \\
\text { form to ensure that utility is } \\
\text { monotonically increasing and concave } \\
\text { - Various personal and household } \\
\text { socio-economic factors are controlled } \\
\text { in the analysis }\end{array}$ & $\begin{array}{l}\text { - Allocation of weekly discretionary time } \\
\text { between weekday/weekends and in- } \\
\text { home/out-of-home is influenced by } \\
\text { household and individual socio- } \\
\text { demographic and work-related } \\
\text { characteristics } \\
\text { - Age is the single most important factor } \\
\text { determining discretionary time split ( } \\
\text { older people have stronger in-home } \\
\text { orientation) } \\
\text { - Time split is also affected by number } \\
\text { of young children, number of adults in } \\
\text { the household, number of autos, work } \\
\text { duration during the weekend and travel } \\
\text { time to work } \\
\text { - Employment status has no statistical } \\
\text { significance on time split }\end{array}$ \\
\hline
\end{tabular}




\begin{tabular}{|c|c|c|c|}
\hline $\begin{array}{l}\text { ते } \\
\text { ڤn }\end{array}$ & $\begin{array}{l}\text { Sample size; geographic } \\
\text { scale; data used }\end{array}$ & $\begin{array}{l}\text { Estimation process; } \\
\text { relevant variables }\end{array}$ & Findings \\
\hline 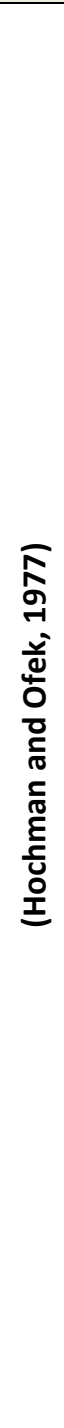 & & $\begin{array}{l}\text { - Partial equilibrium model similar to } \\
\text { the one used by Richard Muth (1969) } \\
\text { is used to analyze the link between } \\
\text { the value of travel time and residential } \\
\text { location } \\
\text { - The model recognizes that the } \\
\text { residential location is affected by the } \\
\text { value of time through the cost of } \\
\text { commuting as well as through its role } \\
\text { in the cost of consumption activities } \\
\text { other than commuting }\end{array}$ & $\begin{array}{l}\text { - Under fairly plausible conditions high } \\
\text { wage earners may still choose to reside } \\
\text { farther away from urban centers even if } \\
\text { housing is an inferior good } \\
\text { - Households with lower unearned } \\
\text { income tend to locate closer to urban } \\
\text { centers compared to wealthier } \\
\text { households } \\
\text { - Pure wage earners tend to locate in } \\
\text { the following order: the group with the } \\
\text { lower share of housing in consumption } \\
\text { tend to locate closer to central business } \\
\text { district (CBD), and the group with larger } \\
\text { share of housing will locate farther } \\
\text { away } \\
\text { - When both income elasticity of } \\
\text { housing and elasticity of substitution } \\
\text { between housing and other goods are } \\
\text { greater than one, high (low) wage } \\
\text { earners will reside farther away from } \\
\text { (closer to) the CBD } \\
\text { - When both elasticities are less than } \\
\text { one, high (low) wage earners will reside } \\
\text { closer to (farther away from) the center } \\
\text { - Households of working wives will } \\
\text { reside closer to the CBD } \\
\text { - Larger families tend to reside further } \\
\text { away from the CBD than smaller ones }\end{array}$ \\
\hline
\end{tabular}

49

Center for Urban Transportation Research | National Center for Transit Research 


\begin{tabular}{|c|c|c|c|}
\hline$\frac{7}{0}$ & $\begin{array}{c}\text { Sample size; geographic } \\
\text { scale; data used }\end{array}$ & $\begin{array}{c}\text { Estimation process; } \\
\text { relevant variables }\end{array}$ & Findings \\
\hline 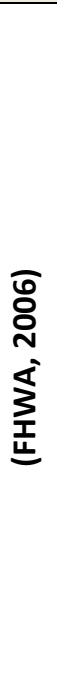 & & $\begin{array}{l}\text { - The report provides guidance for } \\
\text { practitioners on the issues related to } \\
\text { defining, understanding and } \\
\text { measuring travel time reliability } \\
\text { - The report also illustrates steps to } \\
\text { calculate reliability measures using } \\
\text { case studies }\end{array}$ & $\begin{array}{l}\text { - Four measures of travel time reliability } \\
\text { are recommended: } \\
\text { 1. 90-th or 95-th percentile travel time } \\
\text { 2. Buffer index } \\
\text { 3. Planning time index } \\
\text { 4. Frequency that congestion exceeds } \\
\text { some expected threshold } \\
\text { - FHWA discourages the use of } \\
\text { statistical measures of variability, such } \\
\text { as standard deviation and coefficient of } \\
\text { variation, since they are not readily } \\
\text { understood by non-technical audiences }\end{array}$ \\
\hline 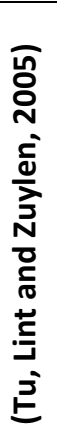 & $\begin{array}{l}\text { - Real-time traffic data collected } \\
\text { from mixed freeway and urban } \\
\text { network in the south-west of } \\
\text { Netherlands, } 2002 \\
\text { - Data consists of 1-minute } \\
\text { aggregate speed and flow } \\
\text { observations (collected by } \\
\text { inductive loops) }\end{array}$ & $\begin{array}{l}\text { - Travel time reliability is defined as } \\
\text { the probability that a certain trip can } \\
\text { be made successfully within a } \\
\text { specified travel time as a function of } \\
\text { route-based traffic density } \\
\text { - Two-dimensional graphical approach } \\
\text { is used to investigate travel time } \\
\text { reliability for a given corridor }\end{array}$ & $\begin{array}{l}\text { - Graphical representation of travel } \\
\text { time reliability allows for intuitive } \\
\text { perception of how, and under what } \\
\text { circumstances, a required level of travel } \\
\text { time reliability can be achieved } \\
\text { - Since prevailing traffic conditions can } \\
\text { be measured in real-time, it is proposed } \\
\text { that travel time reliability is used in } \\
\text { real-time monitoring systems as well }\end{array}$ \\
\hline 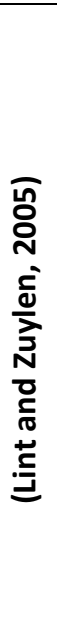 & $\begin{array}{l}\text { - Travel time data from the } \\
\text { motorway in the metropolitan } \\
\text { area or Rotterdam, Netherlands, } \\
\text { collected between } 8 \text { a.m. and } 6 \\
\text { p.m. for the entire year of } 2002 \\
\text { - Travel times were estimated with } \\
\text { the piece-wise linear speed-based } \\
\text { trajectory algorithm }\end{array}$ & $\begin{array}{l}\text { - Unreliability is defined as variability } \\
\text { of travel time across different days of } \\
\text { the week (DOW) and different times } \\
\text { of the day (TOD) } \\
\text { - Two measures of unreliability are } \\
\text { suggested: } \\
\text { 1. Skew (describing the skew of the } \\
\text { distribution of travel time) } \\
\text { 2. Relative width of the distribution } \\
\text { - High value for each metric indicates } \\
\text { high unreliability of travel }\end{array}$ & $\begin{array}{l}\text { - Both skew and width of the } \\
\text { distribution of travel times between } \\
\text { TOD and DOW are relevant indicators } \\
\text { of (un)reliability } \\
\text { - Using the suggested two metrics a } \\
\text { clear distinction can be made between } \\
\text { different phases of traffic flow } \\
\text { operations (free-flow, congested, or } \\
\text { transient) } \\
\text { - The metrics can be used not only to } \\
\text { identify the unreliability of travel times } \\
\text { but also to identify DOW-TOD periods in } \\
\text { which congestion sets in or dissolves }\end{array}$ \\
\hline
\end{tabular}

50

Center for Urban Transportation Research | National Center for Transit Research 


\begin{tabular}{|c|c|c|c|}
\hline 훌 & $\begin{array}{l}\text { Sample size; geographic } \\
\text { scale; data used }\end{array}$ & $\begin{array}{c}\text { Estimation process; } \\
\text { relevant variables }\end{array}$ & Findings \\
\hline 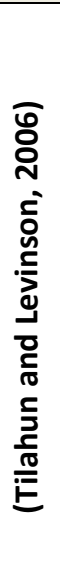 & $\begin{array}{l}\text { - A computer-administered stated } \\
\text { preference survey regarding the } \\
\text { hypothetical route choices } \\
\text { - Data sample covers responses } \\
\text { from } 177 \text { randomly selected } \\
\text { University of Minnesota } \\
\text { employees }\end{array}$ & $\begin{array}{l}\text { - Mode rather than mean travel time } \\
\text { is considered the important basis for } \\
\text { travel time decisions } \\
\text { - Three different measures of } \\
\text { reliability are investigated: } \\
\text { 1. Expected lateness and earliness } \\
\text { relative to the usual travel time } \\
\text { 2. Right side of travel time distribution } \\
\text { (probability of being late) } \\
\text { 3. Standard deviation }\end{array}$ & $\begin{array}{l}\text { - Reducing one minute of the average } \\
\text { experienced lateness is valued by } \\
\text { travelers very close to reducing travel } \\
\text { time } \\
\text { - In all reviewed cases, reliability is } \\
\text { valued highly but differently, depending } \\
\text { on how reliability is defined }\end{array}$ \\
\hline 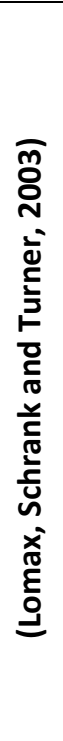 & $\begin{array}{l}\text { - Travel time data from "11 famous } \\
\text { commutes" in the Seattle (WA) } \\
\text { metropolitan area }\end{array}$ & $\begin{array}{l}\text { - The report provides guidelines for } \\
\text { developing reliability measures as a } \\
\text { component of mobility performance } \\
\text { metrics } \\
\text { - All reviewed reliability measures are } \\
\text { grouped into three large categories: } \\
\text { 1) statistical range } \\
\text { 2) buffer time measures } \\
\text { 3) tardy trip indicators }\end{array}$ & $\begin{array}{l}\text { - The report reviews the application of } \\
\text { numerous reliability measures: } \\
\text { - The following three measures of } \\
\text { reliability are recommended: } \\
\text { 1. Percent variation } \\
\text { 2. Buffer time index } \\
\text { 3. Misery index } \\
\text { - Time variability is impacted by several } \\
\text { factors (work zones, weather, } \\
\text { fluctuations in demand, special events, } \\
\text { etc.) and it is important to capture the } \\
\text { contribution of each factor to total } \\
\text { variability }\end{array}$ \\
\hline 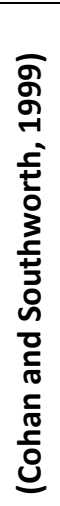 & & $\begin{array}{l}\text { - The study develops a model of traffic } \\
\text { incident-based delays for freeways of } \\
\text { different capacities } \\
\text { - Reliability is measured based on } \\
\text { mean and variance of travel times } \\
\text { - The potential benefits of reducing } \\
\text { travel time variability are } \\
\text { demonstrated using two simple } \\
\text { models ( chosen from the reviewed } \\
\text { literature) }\end{array}$ & $\begin{array}{l}\text { - Model estimation using hypothetical } \\
\text { scenarios from the previous empirical } \\
\text { work (by Small et al.) finds that } \\
\text { reliability is valued very highly by the } \\
\text { commuters, often higher than in-vehicle } \\
\text { travel time } \\
\text { - Significant benefits can be realized by } \\
\text { commuters from reducing variability } \\
\text { even if average trip times change little } \\
\text { or not at all }\end{array}$ \\
\hline
\end{tabular}




\begin{tabular}{|c|c|c|c|}
\hline $\begin{array}{l}\frac{\lambda}{0} \\
\text { Dे } \\
\text { n }\end{array}$ & $\begin{array}{c}\text { Sample size; geographic } \\
\text { scale; data used }\end{array}$ & $\begin{array}{l}\text { Estimation process; } \\
\text { relevant variables }\end{array}$ & Findings \\
\hline 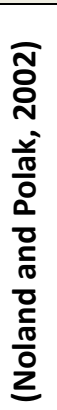 & & $\begin{array}{l}\text { - The paper reviews a number of } \\
\text { theoretical and empirical models of } \\
\text { estimating travel time variability } \\
\text { based on stated preference } \\
\text { techniques }\end{array}$ & $\begin{array}{l}\text { - Scheduling approach to modeling } \\
\text { reliability is better capable of capturing } \\
\text { the responses of travelers to travel time } \\
\text { variability (reliability) compared to the } \\
\text { mean-variance approach } \\
\text { - In certain limited cases, both } \\
\text { approaches can be equivalent }\end{array}$ \\
\hline 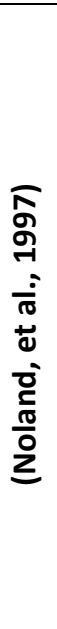 & $\begin{array}{l}\text { - Stated preference survey of } \\
\text { commuters in Los Angeles region } \\
\text { - Data includes } 4,340 \text { usable } \\
\text { observations (responses from } 543 \\
\text { individuals) }\end{array}$ & $\begin{array}{l}\text { - Simulation model that captures the } \\
\text { interaction among scheduling choices, } \\
\text { reliability of travel time and } \\
\text { congestion } \\
\text { - Travelers' choices and travel } \\
\text { conditions are determined } \\
\text { endogenously } \\
\text { - The model combines a supply side } \\
\text { model of congestion delay and a } \\
\text { discrete choice econometric demand } \\
\text { model that predicts scheduling choices }\end{array}$ & $\begin{array}{l}\text { - Scheduling costs account for about } \\
15 \% \text { of the costs of congestion and } \\
\text { unreliability } \\
\text { - About } 37 \% \text { of costs of unexpected } \\
\text { travel time variability can be attributed } \\
\text { to the extra probability of late arrival to } \\
\text { work } \\
\text { - People's aversion to uncertainty can } \\
\text { be explained in terms of costs of early } \\
\text { and late arrivals } \\
\text { - The ratio of standard deviation of } \\
\text { travel time to mean is estimated at } 1.27\end{array}$ \\
\hline 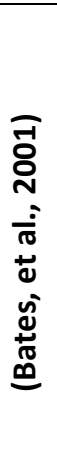 & & $\begin{array}{l}\text { - An overview of the theory behind } \\
\text { valuation of reliability } \\
\text { - Empirical issues in data collection } \\
\text { (specifically, the inaccuracy of SP } \\
\text { approach) are discussed } \\
\text { - The analysis briefly describes a major } \\
\text { investigation into rail passengers' } \\
\text { valuation of service reliability }\end{array}$ & $\begin{array}{l}\text { - Travelers highly value reliability } \\
\text { - Reliability can be valued higher than } \\
\text { travel time, but extremely high } \\
\text { estimates (reliability ratio of } 2 \text { or } \\
\text { higher) are unlikely } \\
\text { - Median and 90-th percentile point of } \\
\text { travel time distribution are better } \\
\text { measures of reliability than mean and } \\
\text { standard deviation }\end{array}$ \\
\hline
\end{tabular}

52

Center for Urban Transportation Research | National Center for Transit Research 


\begin{tabular}{|c|c|c|c|}
\hline$\frac{7}{0}$ & $\begin{array}{c}\text { Sample size; geographic } \\
\text { scale; data used }\end{array}$ & $\begin{array}{c}\text { Estimation process; } \\
\text { relevant variables }\end{array}$ & Findings \\
\hline 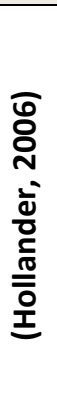 & & $\begin{array}{l}\text { - Different multinomial logit models } \\
\text { where travel time variability is } \\
\text { considered either directly or indirectly, } \\
\text { are reviewed and compared } \\
\text { - The analysis covers different } \\
\text { transportation modes (car, bus and } \\
\text { rail) }\end{array}$ & $\begin{array}{l}\text { - Using mean-variance approach } \\
\text { significantly undervalues the impact of } \\
\text { travel time variability and should be } \\
\text { avoided } \\
\text { - The use of normal distribution for } \\
\text { coefficients in mixed logit models may } \\
\text { be inappropriate and may decrease the } \\
\text { reliability of estimates }\end{array}$ \\
\hline 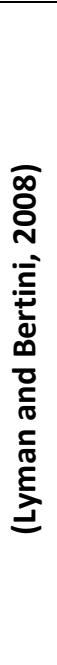 & & $\begin{array}{l}\text { - The paper demonstrates the use of } \\
\text { several reliability measures, including } \\
\text { 95-th percentile travel time, travel } \\
\text { time index, buffer index, planning time } \\
\text { index, and congestion frequency }\end{array}$ & $\begin{array}{l}\text { - Travelers are less concerned with the } \\
\text { actual time that their trip takes than } \\
\text { with the consistency of travel time } \\
\text { - Metropolitan planning organizations } \\
\text { (MPO) should: } \\
\text { 1) Incorporate travel time reliability as a } \\
\text { system-wide goal } \\
\text { 2) Evaluate roadway segments } \\
\text { according to travel time reliability } \\
\text { measures } \\
\text { 3) Prioritize roadway segments using } \\
\text { measures of travel time reliability }\end{array}$ \\
\hline 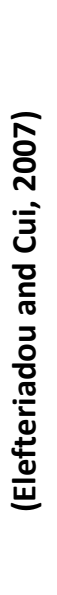 & - Field data from Philadelphia, PA & $\begin{array}{l}\text { - The report reviews the approaches } \\
\text { to modeling and estimating travel } \\
\text { time reliability found in research } \\
\text { literature and provides a synthesis of } \\
\text { findings and recommendations }\end{array}$ & $\begin{array}{l}\text { - Reliability should be defined in terms } \\
\text { of the percentage of trips that reach } \\
\text { destination over a designated facility } \\
\text { within a given travel time } \\
\text { - On-time arrivals should be defined as } \\
10 \text { mph below the speed limit, which } \\
\text { gives } 96 \% \text { reliability } \\
\text { - Two approaches were demonstrated } \\
\text { for empirical estimation of travel time } \\
\text { per mile: } 1 \text { ) when travel time data are } \\
\text { available, and 2) when travel time data } \\
\text { are not available }\end{array}$ \\
\hline
\end{tabular}

53

Center for Urban Transportation Research | National Center for Transit Research 
[This page intentionally left blank.]

54

Center for Urban Transportation Research | National Center for Transit Research 


\section{Appendix B - Summary Table of Empirical Work}

\begin{tabular}{|c|c|c|c|}
\hline 总 & $\begin{array}{l}\text { Sample size; } \\
\text { geographic scale; } \\
\text { data used }\end{array}$ & $\begin{array}{l}\text { Estimation process; } \\
\text { relevant variables }\end{array}$ & Findings \\
\hline 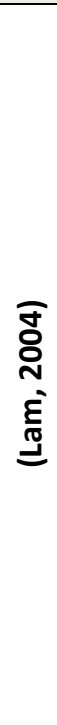 & $\begin{array}{l}\text { - Travel data from State route } 91 \\
\text { and I-15 in California }\end{array}$ & $\begin{array}{l}\text { - Monte Carlo simulation is applied to } \\
\text { scheduling and route choices of } \\
\text { individuals to examine and compare the } \\
\text { welfare of conventional road expansion } \\
\text { policies and value-priced projects } \\
\text { - Individual's route and scheduling } \\
\text { choices are based on the model of Lam } \\
\text { (2000) } \\
\text { - Travel choices are interacted in } \\
\text { accordance with behavioral rules to } \\
\text { produce time savings benefits and } \\
\text { scheduling benefits in different } \\
\text { scenarios of the study }\end{array}$ & $\begin{array}{l}\text { - While the tolled lanes in value-pricing } \\
\text { projects yield the most benefits to } \\
\text { commuters with high value of time, } \\
\text { free lane users also benefit indirectly } \\
\text { from the increased capacity when } \\
\text { commuters switch to tolled lanes } \\
\text { - Value-priced projects are found to } \\
\text { produce consistently larger aggregate } \\
\text { benefits in terms of welfare compared } \\
\text { to conventional road expansion } \\
\text { policies } \\
\text { - Various simulations produce value of } \\
\text { time with mean of } \$ 9 / \text { hour or } \\
\$ 21 / \text { hour, and standard deviation of } \\
\$ 10.50 / \text { hour }\end{array}$ \\
\hline 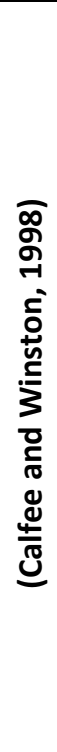 & $\begin{array}{l}\text { - National Family Opinion survey } \\
\text { (mail survey) } \\
\text { - Data covers a random sample of } \\
1,170 \text { automobile commuters } \\
\text { from major U.S. metropolitan } \\
\text { areas who regularly drove to } \\
\text { work }\end{array}$ & $\begin{array}{l}\text { - The analysis estimates automobile } \\
\text { commuters' willingness to pay to save } \\
\text { travel time } \\
\text { - Willingness to pay is examined under } \\
\text { a variety of travel conditions and } \\
\text { assumptions about how toll revenue } \\
\text { will be spent }\end{array}$ & $\begin{array}{l}\text { - There is no evidence that commuters } \\
\text { willingness to pay depended on how } \\
\text { the toll revenue is spent } \\
\text { - Average willingness to pay to reduce } \\
\text { travel time was estimated in the range } \\
\text { of } 14 \%-26 \% \text { of the gross hourly wage, } \\
\text { with an average of } 19 \% \text { for the entire } \\
\text { sample, and is insensitive to travel } \\
\text { conditions } \\
\text { - Travelers are able to adjust to } \\
\text { congestion through their modal, } \\
\text { residential, workplace and departure } \\
\text { time choices (this implies that even } \\
\text { high-income commuters may be } \\
\text { unable to benefit substantially from } \\
\text { tolls) }\end{array}$ \\
\hline
\end{tabular}




\begin{tabular}{|c|c|c|c|}
\hline$\frac{7}{0}$ & $\begin{array}{c}\text { Sample size; } \\
\text { geographic scale; } \\
\text { data used }\end{array}$ & $\begin{array}{c}\text { Estimation process; } \\
\text { relevant variables }\end{array}$ & Findings \\
\hline 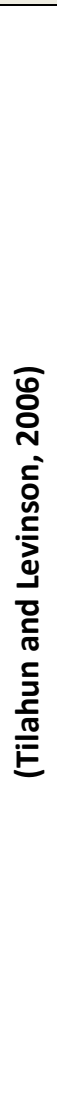 & $\begin{array}{l}\text { - The analysis uses the data from } \\
\text { stated preference survey of } 700 \\
\text { travelers on I-394, in } \\
\text { Minneapolis/St. Paul area } \\
\text { - The survey participants were } \\
\text { asked about the trips they have } \\
\text { taken before, and asked if they } \\
\text { would opt for the free route or } \\
\text { pay and go on the high } \\
\text { occupancy/toll (HOT) lanes }\end{array}$ & $\begin{array}{l}\text { - Random parameter logit model is used } \\
\text { - The study estimates value of time } \\
\text { differences between people who } \\
\text { arrived at their destination as planned } \\
\text { and those that were delayed } \\
\text { - Subscribers and non-subscribers of } \\
\text { MnPass (electronic toll collection } \\
\text { system) are analyzed separately }\end{array}$ & $\begin{array}{l}\text { - MnPass subscribers that were } \\
\text { early/on-time value their time much } \\
\text { lower ( } \$ 10.62 / \mathrm{hr}) \text { than those that } \\
\text { were late }(\$ 25.42 / \mathrm{hr}) \text {, during } \\
\text { afternoon peak (4:00-6:00 p.m.) } \\
\text { - No significant difference for MnPass } \\
\text { subscribers was detected for off-peak } \\
\text { and morning peak (7:00-9:30 a.m.) } \\
\text { - For non-subscribers the order is } \\
\text { reversed: } \$ 13.63 / \mathrm{hr} \text { for commuters } \\
\text { that are early/on-time vs. } \$ 10.10 / \mathrm{hr} \\
\text { for commuters who are late in the } \\
\text { morning peak period } \\
\text { - Subscribers who were late in the } \\
\text { afternoon rush hour had higher } \\
\text { willingness to pay to reduce travel } \\
\text { time }\end{array}$ \\
\hline
\end{tabular}




\begin{tabular}{|c|c|c|c|}
\hline$\frac{\lambda}{0}$ & $\begin{array}{c}\text { Sample size; } \\
\text { geographic scale; } \\
\text { data used }\end{array}$ & $\begin{array}{c}\text { Estimation process; } \\
\text { relevant variables }\end{array}$ & Findings \\
\hline 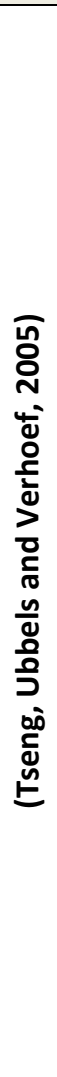 & $\begin{array}{l}\text { - Interactive computer-based } \\
\text { survey among Dutch commuters, } \\
\text { collected during three weeks in } \\
\text { June } 2004 \\
\text { - Data covered 6,800 working } \\
\text { adults who drive to work by car } \\
\text { two or more times per week, and } \\
\text { who face congestion of } 10 \text { or } \\
\text { more minutes for at least two } \\
\text { times a week }\end{array}$ & $\begin{array}{l}\text { - The analysis empirically estimates } \\
\text { travelers' valuation of travel time, } \\
\text { scheduled delay and uncertainty } \\
\text { - Multinomial logit model is used to } \\
\text { estimate choices of the motorists } \\
\text { - Socio-economic characteristics } \\
\text { controlled: income, education, and } \\
\text { arrival/departure time restrictions }\end{array}$ & $\begin{array}{l}\text { - The value of time is higher for } \\
\text { travelers when they are late } \\
\text { - Mean value of time for all travelers is } \\
10 \text { Euros/hour ( } \$ 12.10 / \mathrm{hr}^{*} \text { ), and the } \\
\text { value of schedule delay late (VSDL) has } \\
\text { the mean value of } 14 \text { Euros/hour } \\
\text { (\$16.94/hr*) } \\
\text { - Inflexible commuters generally have } \\
\text { a higher value of time, schedule delay } \\
\text { and uncertainty } \\
\text { - Reliability is valued at roughly half of } \\
\text { the value of time (5.3 Euros/hr = } \\
\$ 6.41 / \text { hr*) } \\
\text { - Commuters prefer the car over the } \\
\text { public transportation alternative } \\
\text { - People's aversion to arriving early is } \\
\text { increasing non-linearly as their } \\
\text { schedule delay early time increases } \\
\text { - Income and the length of commuting } \\
\text { trip affect the value of time }\end{array}$ \\
\hline
\end{tabular}




\begin{tabular}{|c|c|c|c|}
\hline$\frac{\pi}{0}$ & $\begin{array}{c}\text { Sample size; } \\
\text { geographic scale; } \\
\text { data used }\end{array}$ & $\begin{array}{c}\text { Estimation process; } \\
\text { relevant variables }\end{array}$ & Findings \\
\hline 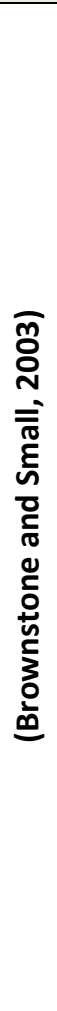 & $\begin{array}{l}\text { - Travel data from electronic toll } \\
\text { collection facilities in HOT lanes } \\
\text { on SR-91 and I-15 in Southern } \\
\text { California (revealed behavior) } \\
\text { - Stated preference data is } \\
\text { collected through a panel survey } \\
\text { of travelers in the corridor } \\
\text { - Five separate data sets were } \\
\text { collected between } 1996 \text { and } 2000\end{array}$ & $\begin{array}{l}\text { - The paper reports the results of the } \\
\text { evaluations of two road pricing } \\
\text { demonstrations in Southern California } \\
\text { (on SR-91 and I-15) } \\
\text { - The goal was the empirical estimation } \\
\text { of commuters' value of time and } \\
\text { reliability } \\
\text { - The estimation is performed using the } \\
\text { model adapted from Small, Winston, } \\
\text { and Yan (2002) }\end{array}$ & $\begin{array}{l}\text { - Based on the revealed behavior, the } \\
\text { value of time saved on the morning } \\
\text { commute is estimated at } \$ 20 \text { to } \$ 40 \\
\text { per hour, which is } 50 \%-90 \% \text { of the } \\
\text { average wage rate in the sample } \\
\text { - When stated preference is used, the } \\
\text { value of time is estimated at less than } \\
\text { half of the revealed preferences } \\
\text { - Reliability, defined as an upper tale of } \\
\text { the travel-time distribution (e.g., the } \\
\text { difference between } 90-\text { th and } 50 \text {-th } \\
\text { percentile), is valued at } 95 \%-140 \% \text { of } \\
\text { the median travel time } \\
\text { - Women value reliability much higher } \\
\text { than men (possibly due to higher child- } \\
\text { care responsibilities and less flexibility } \\
\text { in schedule) }\end{array}$ \\
\hline
\end{tabular}




\begin{tabular}{|c|c|c|c|}
\hline$\frac{7}{0}$ & $\begin{array}{c}\text { Sample size; } \\
\text { geographic scale; } \\
\text { data used }\end{array}$ & $\begin{array}{c}\text { Estimation process; } \\
\text { relevant variables }\end{array}$ & Findings \\
\hline 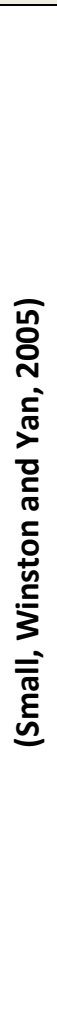 & $\begin{array}{l}\text { - RP and SP travel data from SR- } \\
91 \text { in greater Los Angeles area } \\
\text { (CA) collected over a ten-month } \\
\text { period in } 1999 \text { and } 2000 \\
\text { - The final sample consisted of RP } \\
\text { data on } 522 \text { individuals and SP } \\
\text { data on } 81 \text { distinct individuals }\end{array}$ & $\begin{array}{l}\text { - Mixed logit model is used to evaluate } \\
\text { both RP and SP data on commuter } \\
\text { choices of whether to pay toll for } \\
\text { congestion-free express travel }\end{array}$ & $\begin{array}{l}\text { - Travel time and reliability of travel } \\
\text { time are highly valued by motorists } \\
\text { and there is substantial heterogeneity } \\
\text { in these values within the sample } \\
\text { - Women, middle-aged motorists, and } \\
\text { motorists in smaller households are } \\
\text { more likely to choose toll lanes } \\
\text { - Based on commuters' RP, the median } \\
\text { value of time is estimated at } \\
\$ 21.46 / \text { hour, or about } 93 \% \text { of the } \\
\text { average wage rate } \\
\text { - The median RP value of reliability is } \\
\$ 19.56 / \text { hour } \\
\text { - Reliability accounts for one-third of } \\
\text { the express lanes savings - less during } \\
\text { the early and middle part of the rush } \\
\text { hour, and more during the later part } \\
\text { - SP values of time and reliability are } \\
\text { much smaller than RP values }\end{array}$ \\
\hline 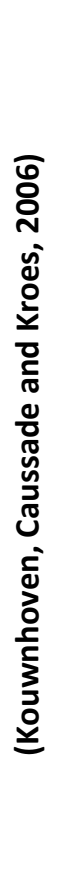 & $\begin{array}{l}\text { - Large-scale SP data set of } \\
\text { preferences of Paris railway } \\
\text { commuters (travelling to/from } \\
\text { Paris, France) } \\
\text { - Sample consists of 1,273 survey } \\
\text { responses, collected in May-June } \\
2004\end{array}$ & $\begin{array}{l}\text { - Discrete choice model is used to } \\
\text { estimate key parameters needed to } \\
\text { determine the value of reliability of } \\
\text { travel time }\end{array}$ & $\begin{array}{l}\text { - The extra disutility corresponding to } \\
\text { each step in the level of delays } \\
\text { decreases as the number of delays } \\
\text { increases } \\
\text { - The value of time for people } \\
\text { commuting or travelling for education } \\
\text { purposes is higher than for people } \\
\text { travelling for other purposes } \\
\text { - People dislike arriving late for/from } \\
\text { their work/study more than arriving } \\
\text { for/from other purpose destinations } \\
\text { - On lines with higher regularity, } \\
\text { having a seat is mainly valued for } \\
\text { longer trips } \\
\text { - On lines with bad regularity, having a } \\
\text { seat is always valued highly, regardless } \\
\text { of the length of the trip }\end{array}$ \\
\hline
\end{tabular}




\begin{tabular}{|c|c|c|c|}
\hline 咅 & $\begin{array}{c}\text { Sample size; } \\
\text { geographic scale; } \\
\text { data used }\end{array}$ & $\begin{array}{c}\text { Estimation process; } \\
\text { relevant variables }\end{array}$ & Findings \\
\hline 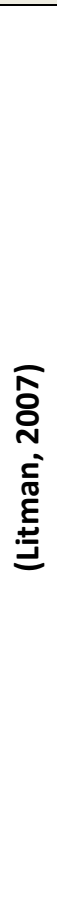 & & $\begin{array}{l}\text { - The study provides a synthesis of } \\
\text { previous and current studies on the } \\
\text { value of travel time } \\
\text { - The report recommends specific travel } \\
\text { time value adjustments to account for } \\
\text { factors such as travel and waiting } \\
\text { comfort, travel reliability, and real time } \\
\text { transit vehicle arrival information }\end{array}$ & $\begin{array}{l}\text { - Travel quality improvements reduce } \\
\text { travel time unit cost by } 10 \% \text { providing } \\
\text { benefits equivalent to travel speed } \\
\text { operational improvements } \\
\text { - If transit service is convenient and } \\
\text { comfortable, transit travel costs are } \\
\text { about } 25 \%-35 \% \text { of prevailing wages, } \\
\text { compared to } 35 \%-50 \% \text { for drivers } \\
\text { - Transit travel time may be valued at } \\
25 \% \text { of wage rate when sitting, } 50 \% \text { of } \\
\text { wages when standing, } 100 \% \text { in a } \\
\text { crowded transit vehicle, and } 175 \% \text { of } \\
\text { wages when waiting under unpleasant } \\
\text { conditions } \\
\text { - Each minute of delay beyond } \\
\text { published schedule should be valued } \\
3-5 \text { times the standard in-vehicle } \\
\text { travel time }\end{array}$ \\
\hline 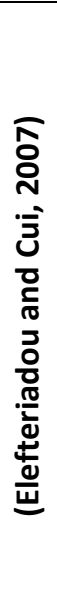 & $\begin{array}{l}\text { - The estimation of the model is } \\
\text { based on field data from } \\
\text { Philadelphia, PA }\end{array}$ & $\begin{array}{l}\text { - The report reviews the approaches to } \\
\text { modeling and estimating travel time } \\
\text { reliability found in research literature } \\
\text { and provides a synthesis of findings and } \\
\text { recommendations }\end{array}$ & $\begin{array}{l}\text { - Reliability should be defined in terms } \\
\text { of the percentage of trips that reach } \\
\text { destination over a designated facility } \\
\text { within a given travel time } \\
\text { - On-time arrivals should be defined as } \\
10 \mathrm{mph} \text { below the speed limit, which } \\
\text { gives } 96 \% \text { reliability } \\
\text { - Two approaches were demonstrated } \\
\text { for empirical estimation of travel time } \\
\text { per mile: 1) when travel time data are } \\
\text { available, and 2) when travel time data } \\
\text { are not available }\end{array}$ \\
\hline
\end{tabular}

60

Center for Urban Transportation Research | National Center for Transit Research 